Universidad de Lima

Facultad de Comunicación

Carrera de Comunicación

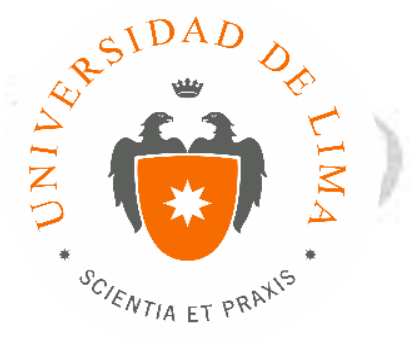

\title{
ANÁLISIS DEL TRATAMIENTO INFORMATIVO DE LOS DIARIOS EL COMERCIO Y LA REPÚBLICA SOBRE LAS POLÍTICAS DE INCLUSIÓN SOCIAL IMPULSADAS DURANTE LOS PRIMEROS 100 DÍAS DEL GOBIERNO DE OLLANTA HUMALA
}

Tesis para optar el Título Profesional de Licenciado en Comunicación

Ricardo Alberto Del Rosario Zárate

Código 20081350

Asesor

Carlos Rivadeneyra Olcese

Lima - Perú

Octubre 2016 


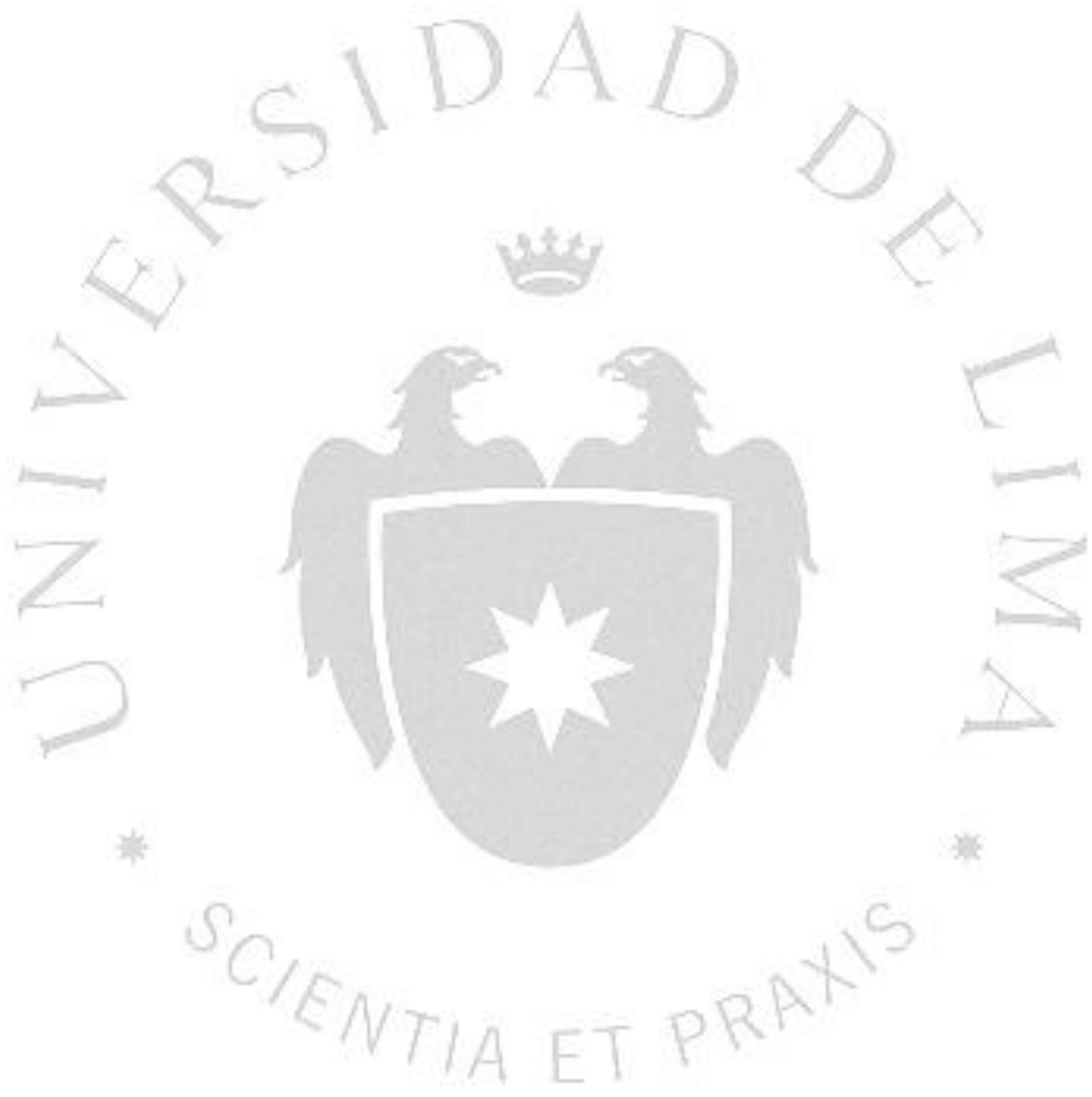




\section{ANÁLISIS DEL TRATAMIENTO INFORMATIVO}

DE LO DIARIOS EL COMERCIO Y LA REPÚBLICA SOBRE LAS POLÍTICAS DE INCLUSIÓN SOCIAL IMPULSADAS DURANTE LOS PRIMEROS 100 DÍAS DEL GOBIERNO DE OLLANTA HUMALA 


\section{TABLA DE CONTENIDO}

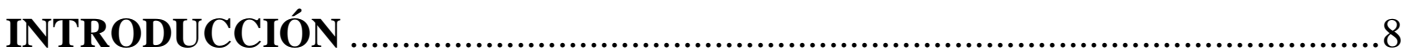

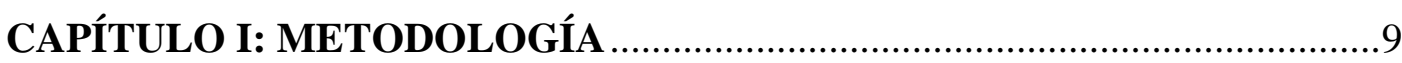

1.1 Propuesta metodológica y preguntas de investigación...............................9

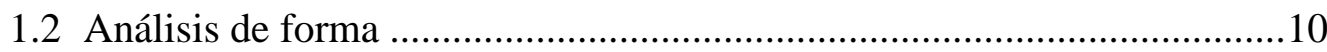

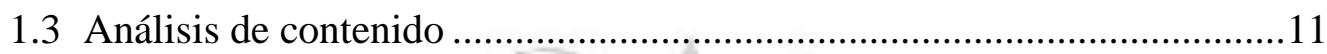

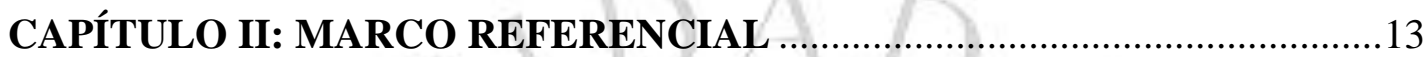

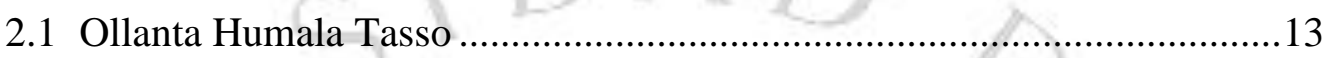

2.2 El triunfo de Humala: Elecciones generales 2011 .................................15

2.3 Los tres programas de Gana Perú ............................................................17

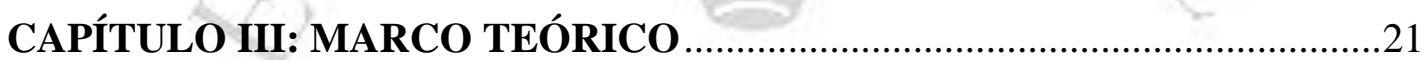

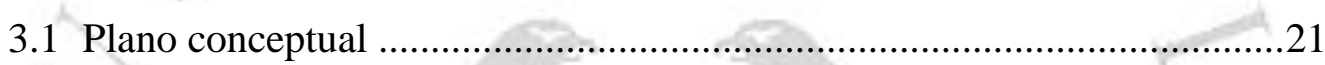

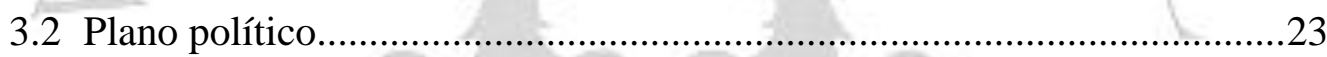

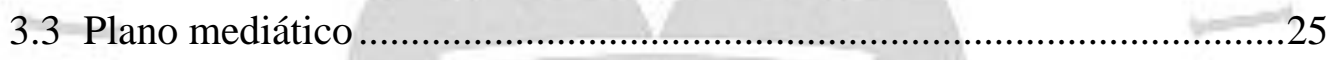

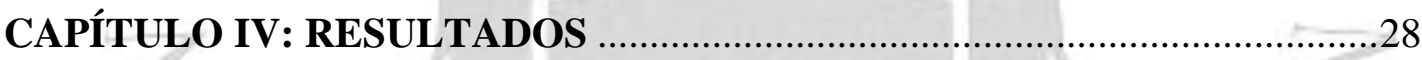

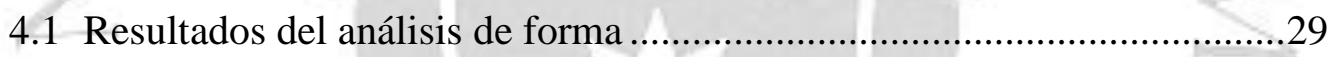

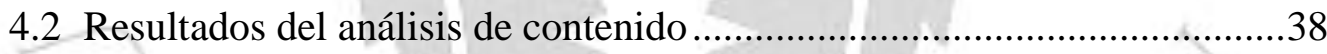

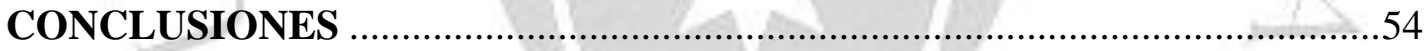

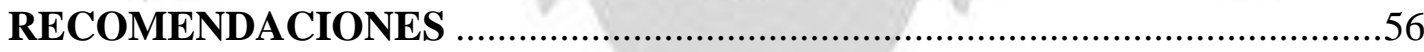

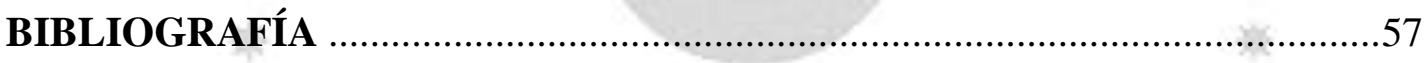

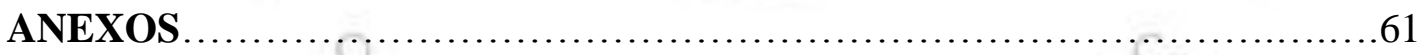




\section{INDICE DE TABLAS}

Tabla 2.2.1 Resultados elecciones generales del Perú 2011 - Primera vuelta..........11

Tabla 2.2.2 Resultados elecciones generales del Perú 2011 - Segunda vuelta........12

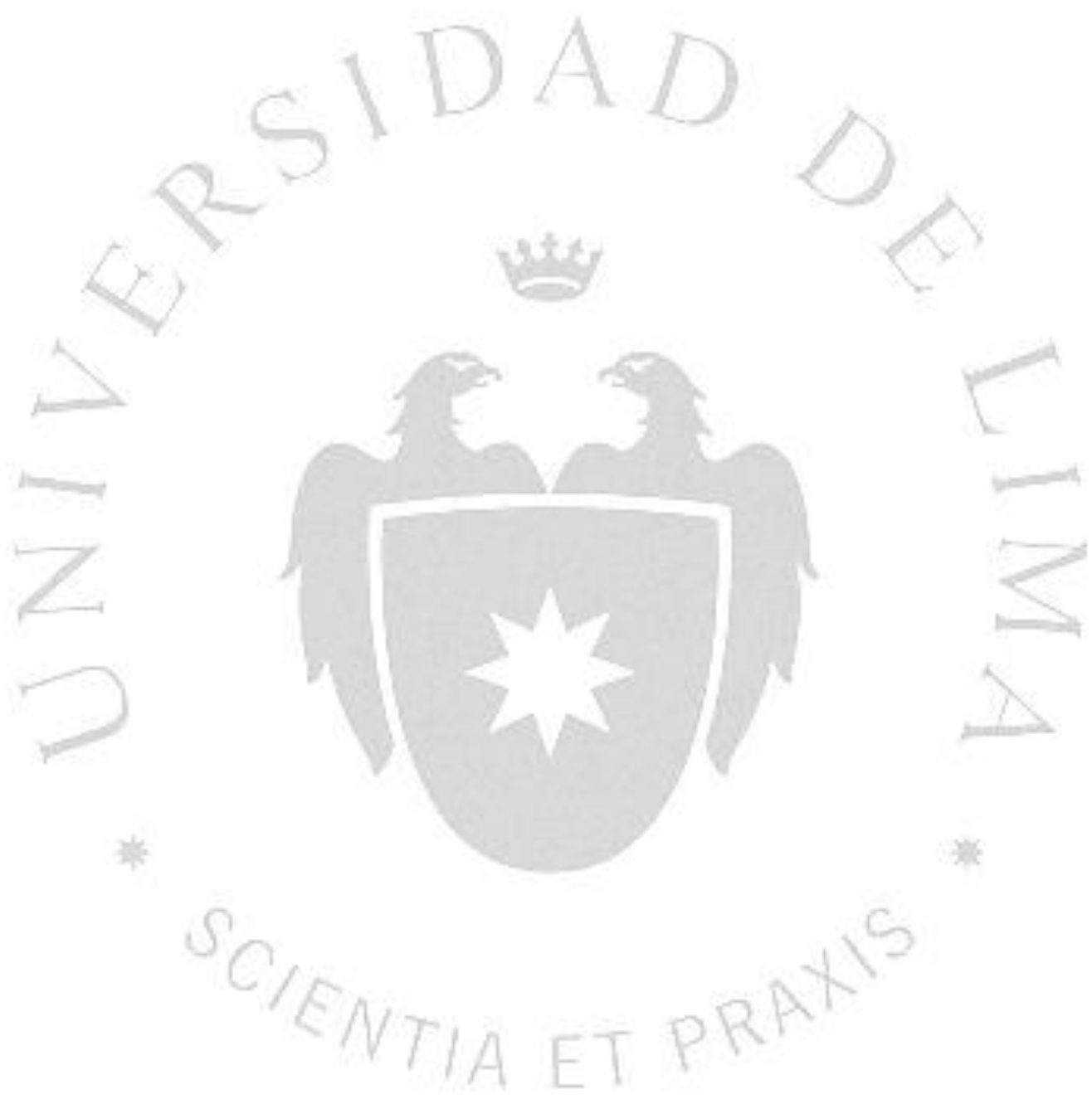




\section{INDICE DE FIGURAS}

Figura 4.1.1.1 Frecuencia de noticias sobre políticas de inclusión social por sección en $\mathrm{La}$

República

$(\%)$

.28

Figura 4.1.1.1 Frecuencia de noticias sobre políticas de inclusión social por sección en El

Comercio

$(\%)$ .29

Figura 4.1.2.1 Frecuencia de actores visibilizados en las fotografías en El Comercio $(\%)$

Figura 4.1.2.2 Frecuencia de actores visibilizados en las fotografías en La República $(\%)$ .32

Figura 4.1.3.1 Frecuencia de actores visibilizados como fuentes en El Comercio $(\%)$

Figura 4.1.3.2 Frecuencia de actores visibilizados como fuentes en La República $(\%)$ .35

Figura 4.1.4.1 Relevancia de las temáticas por ubicación en El Comercio $(\%)$ 37

Figura 4.1.4.2 Relevancia de las temáticas por ubicación en La República $(\%)$ .38

Figura 4.2.1.1 Cantidad de noticias que fueron promesas de campaña en El Comercio $(\%)$ .40

Figura 4.2.1.1 Cantidad de noticias que fueron promesas de campaña en La República $(\%)$

Figura 4.2.2.1 Tendencia de la preferencia del diario sobre la participación del Estado por temáticas

en

$\mathrm{La}$

República. .43

Figura 4.2.2.2 Tendencia de la preferencia del diario sobre la participación del Estado por temáticas

en E1

Comercio .44 
Figura 4.2.3.1 Tendencia de la preferencia del diario sobre la participación del Estado en la economía $\quad$ en $\quad$ El

Comercio .45

Figura 4.2.3.2 Tendencia de la preferencia del diario sobre la participación del Estado en trabajo

en

Comercio 47

Figura 4.2.4.1 Frecuencia de preferencia en publicación por temas generales en El Comercio $(\%)$ .48

Figura 4.2.4.2 Frecuencia de preferencia en publicación por temas generales en La República $(\%)$ .49

Figura 4.2.5.1 Frecuencia de preferencia en publicación por casos específicos en El Comercio $(\%)$ .50

Figura 4.2.5.2 Frecuencia de preferencia en publicación por casos específicos en La

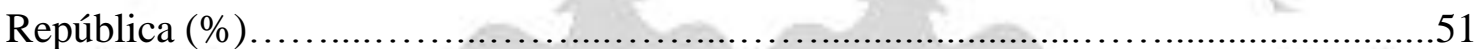
Figura 4.2.6.1 Valoración de cada medio a la performance en las políticas de inclusión social en el Gobierno de Humala tanto en El Comercio como en La República (\%).....52 


\section{INTRODUCCIÓN}

La inclusión social es un tema central y constante en la agenda pública nacional. En el 2011, los dos más importantes medios de prensa del país, El Comercio y La República, se vieron polarizados con respecto a las propuestas programáticas del entonces candidato Ollanta Humala Tasso. Estas prometían lograr dicha inclusión a partir de programas sociales, reformas económicas, lucha frontal contra la corrupción y en general con una participación más activa y estratégica por parte del Estado.

Este trabajo de investigación tiene como base el análisis de contenido y mediante la aplicación de métodos cuantitativos y cualitativos decodificamos el tratamiento informativo de los diarios El Comercio y La República. Tenemos como insumo principal el total de las noticias que publicaron ambos diarios durante los primeros 100 días del Gobierno de Humala y consideramos todas aquellas publicaciones que estuvieran vinculadas a políticas de inclusión social desde un criterio amplio, el cual sustentaremos teóricamente más adelante.

Con este estudio determinaremos cuáles han sido las políticas de inclusión social prioritarias para cada uno de estos diarios, qué diferencias y coincidencias encontramos en su tratamiento informativo y cuáles fueron sus posiciones con respecto a la participación del Estado en dichas reformas.

La inclusión social como concepto es relativamente nuevo en el debate político de nuestro país. Por ello, no encontramos ningún antecedente de investigación académica sobre el análisis de las políticas de inclusión social de un Gobierno a través de un monitoreo de medios. 


\section{CAPÍTULO I: METODOLOGÍA}

\subsection{Propuesta metodológica y preguntas de investigación}

Nuestra metodología central es el análisis de contenido de información acumulada, porque se analizan tanto la forma de la noticia (ubicación, tamaño, fotografía y fuente) como el contenido (el enfoque periodístico y las estrategias que hay detrás de ellas).

Asimismo, se han empleado técnicas de investigación cuantitativa (al generar estadísticas para obtener resultados) y cualitativas (en la articulación y entendimiento de dichos resultados). Con ello queremos determinar mediante nuestras preguntas de investigación ¿Cuáles fueron las políticas de inclusión social priorizadas en el discurso de El Comercio y La República durante los 100 primeros días del Gobierno de Humala?, ¿Qué diferencias y coincidencias se encuentran en el tratamiento periodístico de El Comercio y La República acerca de las políticas de inclusión social durante los 100 primeros días del Gobierno de Humala? Y, finalmente, ¿Cuál ha sido el enfoque periodístico en El Comercio y La República sobre la participación del Estado en las políticas de inclusión social durante los 100 primeros días del Gobierno de Humala?

Acerca del desarrollo de la investigación, nuestros principales insumos fueron las noticias publicadas por los diarios El Comercio y La República desde el 28 de julio (día que asumió el mando el presidente Humala) hasta el 4 de noviembre del 2011 (cuando se cumplen primeros 100 días de su mandato). 


\subsection{Análisis de forma}

La matriz de registro de las noticias se dividirá en dos partes, un análisis de forma y otro de contenido. Para el primero se considerará lo siguiente:

\begin{tabular}{|c|c|c|c|c|c|}
\hline \multicolumn{6}{|c|}{ ANÁLISIS DE FORMA } \\
\hline Fecha & Título & Página/ Sección & Tamaño & Foto & Fuente \\
\hline \multirow[t]{11}{*}{$28 / 07$} & “..." & № / general & 1/8 hoja & -Gobierno & -Gobierno \\
\hline & & № / política & 1/4 hoja & -Congreso & -Congreso \\
\hline & & № / economía & $1 / 2$ hoja & - Líderes de opinión & - Líderes de opinión \\
\hline & & № / regiones & 3/4 hoja & -Empresa & •Empresa \\
\hline & & & 1 hoja & $\bullet$ ONG & •ONG \\
\hline & & & 2 hojas & -Gráficos & $\begin{array}{l}\text { - Organismos } \\
\text { Internacionales }\end{array}$ \\
\hline & & & & -Personas pobres & -El propio diario \\
\hline & & & & $\begin{array}{l}\text {-Personas } \\
\text { trabajando }\end{array}$ & $\begin{array}{l}\text {-Indicadores e } \\
\text { información pública }\end{array}$ \\
\hline & & & & - Lugares y regiones & $\begin{array}{l}\text {-Gobiernos Municipales y } \\
\text { Regionales }\end{array}$ \\
\hline & & & & $\begin{array}{l}\text {-Organizaciones } \\
\text { sociales }\end{array}$ & -Organizaciones sociales \\
\hline & & & & $\begin{array}{l}\text {-Otras instituciones } \\
\text { del Estado }\end{array}$ & $\begin{array}{l}\text { - Otras instituciones del } \\
\text { Estado }\end{array}$ \\
\hline
\end{tabular}

\subsection{Análisis de contenido}

Para esta segunda parte se tendrán en cuenta las siguientes variables:

\begin{tabular}{|c|c|c|c|c|c|}
\hline \multicolumn{6}{|c|}{ ANÁLISIS DE CONTENIDO } \\
\hline $\begin{array}{l}\text { Variables de } \\
\text { políticas de } \\
\text { inclusión social } \\
\text { generales* }\end{array}$ & $\begin{array}{l}\text { Variables de políticas de } \\
\text { inclusión social específicas* }\end{array}$ & $\begin{array}{l}\text { Valoración de } \\
\text { la noticia con } \\
\text { respecto al } \\
\text { Gobierno }\end{array}$ & $\begin{array}{l}\text { ¿Fue } \\
\text { promesa } \\
\text { de } \\
\text { campaña? }\end{array}$ & $\begin{array}{l}\text { Enfoque } \\
\text { periodístico } \\
\text { sobre las } \\
\text { variables } \\
\text { generales* }\end{array}$ & $\begin{array}{l}\text { Enfoque } \\
\text { periodístico } \\
\text { sobre las } \\
\text { variables } \\
\text { específica* }\end{array}$ \\
\hline Seguridad & $\begin{array}{l}\text { - Nueva estrategia \& Conasec } \\
\text { - Más policías en las calles } \\
\text { - Lucha contra el narcotráfico } \\
\text { - Caso Devida }\end{array}$ & $\begin{array}{r}\text { Totalmente a } \\
\text { favor }=5 \\
\text { Respaldo }=4\end{array}$ & $\begin{array}{l}\text { - Sí } \\
\text { •No }\end{array}$ & $\begin{array}{c}\text { (+) Más } \\
\text { participació } \\
\mathrm{n} \text { del } \\
\text { Estado }\end{array}$ & $\begin{array}{c}\text { (+) Más } \\
\text { participació } \\
\mathrm{n} \text { del } \\
\text { Estado }\end{array}$ \\
\hline Economía & $\begin{array}{l}\text { - Gravamen minero } \\
\text { - Crecimiento económico } \\
\text { - Empresas y rol estatal } \\
\text { - Presupuesto y gasto } \\
\text { - Impulso Mypes y Pymes } \\
\text { - Lucha contra la pobreza }\end{array}$ & $\begin{array}{r}\text { Ni a favor ni } \\
\text { en contra }=\mathbf{3} \\
\text { Crítico }=\mathbf{2} \\
\text { Totalmente en } \\
\text { contra }=\mathbf{1}\end{array}$ & & $\begin{array}{c}\text { (-) Menos } \\
\text { participació } \\
\mathrm{n} \text { del } \\
\text { Estado }\end{array}$ & $\begin{array}{c}\text { (-) Menos } \\
\text { participació } \\
\mathrm{n} \text { del } \\
\text { Estado }\end{array}$ \\
\hline Descentralización & $\begin{array}{l}\text { - Macroregiones } \\
\text { - Demandas de las regiones } \\
\text { - Impulso del turismo } \\
\text { - Viajes del Gobierno a regiones }\end{array}$ & $\overline{(+) 54321(-)}$ & & & \\
\hline
\end{tabular}




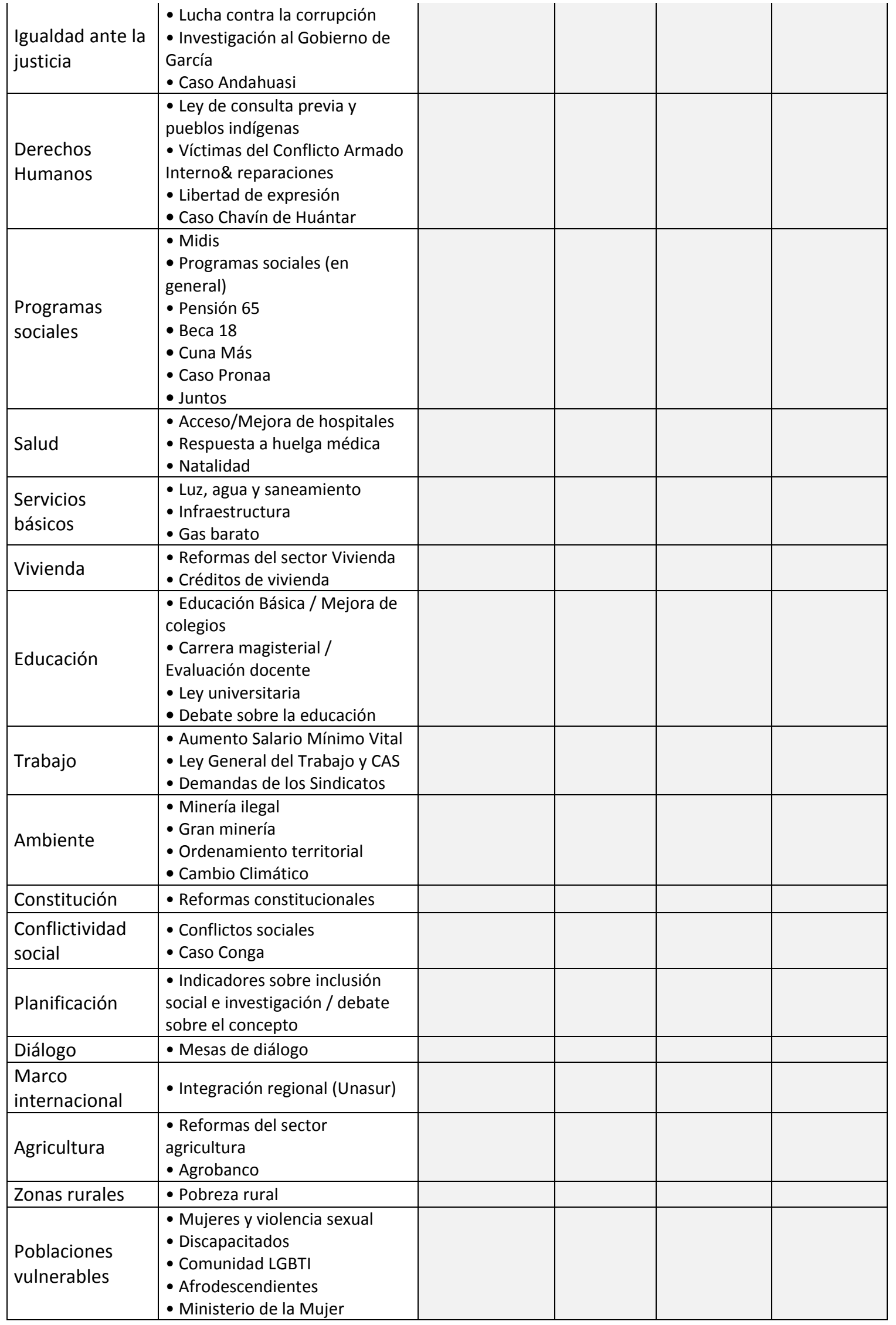




\section{CAPÍTULO II: MARCO REFERENCIAL}

Nuestro marco referencial busca resumir a modo de contextualización la información clave del proceso en el cual Ollanta Humala Tasso fue electo como Presidente de la República del Perú para el periodo 2011-2016.

\subsection{Ollanta Humala Tasso}

El 29 de octubre del año 2000 un militar llamado Ollanta Humala Tasso aparece en la escena política nacional al liderar un levantamiento-sublevación en Locumba (Tacna, Perú) contra el alto mando militar del ex presidente Alberto Fujimori y su asesor Vladimiro Montesinos. Dicho proceso lo condujo a prisión para luego ser amnistiado por el gobierno de transición democrática de Valentín Paniagua. Como militar Humala sirvió en Challapalca, en la Cordillera del Cóndor (conflicto del Cenepa) y en diversas zonas de emergencia y tuvo once procesos entre judiciales y penales, siendo el más mediático el caso Madre Mía en el que fue acusado de violación de derechos humanos.

Humala postuló a las elecciones presidenciales del año 2006 con un discurso y actuación pública considerada por gran parte de la opinión pública como "radical" y se ubicó en segundo lugar tras ser derrotado, en segunda vuelta, por el ex presidente Alan García Pérez. Diversos analistas coinciden en que su cercanía con Hugo Chávez Frías, presidente de Venezuela durante esos años, y la injerencia que tuvo él durante el proceso le costó la elección.

En el 2011, reaparece en el espectro político acompañado de un conjunto de fuerzas de izquierda, nacionalistas y progresistas con quienes, de la mano del empresario Salomón Lerner Ghitis, conforma el partido político Gana Perú. Esta vez Humala tenía una propuesta programática, un equipo de técnicos y ex diputados de izquierda y un discurso mucho más moderado, lo que motivó que la prensa ironice acerca de que "había cambiado el polo rojo por el polo blanco". Luego de pasar a segunda vuelta y tras una polarizada contienda electoral, Humala logra derrotar a Keiko Fujimori, hija del ex presidente Alberto Fujimori, condenado por delitos considerados de lesa humanidad. 
Para el historiador Antonio Zapata ante una falta de liderazgos en la izquierda, esta vio en Humala una suerte de "locomotora" para llegar al poder (RPP, 2016). Ello respondería también a la ausencia de partidos y desafección política hacia las instituciones democráticas en el que, las y los ciudadanos ni siquiera cuestionan su legitimidad (Torcal, 2000).

\subsection{El triunfo de Humala: Elecciones generales 2011}

\section{- Primera vuelta electoral}

Gana Perú planteó una coalición de fuerzas nacionalistas, progresistas y de izquierda conformada por el Partido Nacionalista (que fundó Humala junto a su esposa Nadine Heredia), Ciudadanos por el Cambio (liderado por el empresario Salomón Lerner Ghitis), Partido Socialista (del ex diputado de Izquierda Unida y PUM, Javier Diez Canseco), el Partido Comunista Peruano - PC (plataforma política de la Confederación General de Trabajadores del Perú - CGTP) y un conjunto de organizaciones sociales y regionales. A diferencia del 2006, esta vez Humala estaba acompañado de intelectuales, políticos y técnicos con quienes presenta un extenso programa de gobierno, La gran transformación.

A inicios de la contienda las encuestas parecían no favorecerlo, Datum, Ipsos Perú y CPI lo ubicaban en el quinto lugar con alrededor de un $10 \%$ de intención de voto y quienes lideraban dichas encuestas eran más bien políticos tradicionales como el ex presidente 2001-2006, Alejandro Toledo, el ex alcalde de Lima 2006-2010, Luis Castañeda Lossio y más atrás, la hija del ex presidente Alberto Fujimori, Keiko Fujimori y el ex premier del gobierno de Toledo y ex Ministro de Economía, Pedro Pablo Kuczynski.

A un mes antes de realizarse la primera vuelta la propuesta política de Ollanta Humala crece exponencialmente en las encuestas y logra posicionarse en el primer lugar de preferencias. Ello provocó el recordado titular de "lunes negro" porque el índice general de la Bolsa de Valores de Lima - BVL se derrumbó (Diario Correo, 2011). Ello respondería a un conjunto de cuestionamientos que se hicieron desde los gremios empresariales como Confiep y la Sociedad Nacional de Industrias - SNI, medios de comunicación como El Comercio o Correo y diversos líderes de opinión a la propuesta 
de Gana Perú. Los principales puntos programáticos en cuestión giraban en torno a un impuesto a las sobreganancias mineras, impulsar un rol más protagónico del Estado en actividades estratégicas como energía, modificar la Constitución Política de 1993 y programas sociales como el régimen no contributivo "Pensión 65" que muchos cuestionaron se financiaría con los fondos de las AFP.

Luego de intensos debates y polémicas, el domingo 3 de abril de 2011 se celebró la primera vuelta electoral, cuyos resultados fueron los siguientes (ONPE, 2011):

Tabla 2.2.1Resultados elecciones generales del Perú 2011 - Primera vuelta

\begin{tabular}{|l|c|c|c|}
\hline \multicolumn{1}{|c|}{ Organización política } & Votos & $\begin{array}{c}\% \text { Votos } \\
\text { válidos }\end{array}$ & $\begin{array}{c}\% \text { Votos } \\
\text { emitidos }\end{array}$ \\
\hline Ollanta Humala - Alianza Gana Perú & 4643064 & $31,72 \%$ & $27,80 \%$ \\
\hline Keiko Fujimori - Fuerza 2011 & 3449595 & $23,56 \%$ & $20,65 \%$ \\
\hline Pedro Pablo Kuczynski - Alianza por el Gran Cambio & 2711450 & $18,52 \%$ & $16,23 \%$ \\
\hline Alejandro Toledo - Alianza Perú Posible & 2289561 & $15,64 \%$ & $13,71 \%$ \\
\hline Luis Castañeda - Solidaridad Nacional & 1440143 & $9,83 \%$ & $8,62 \%$ \\
\hline
\end{tabular}

Fuente: Oficina Nacional de Procesos Electorales - ONPE (2011)

\section{- Segunda vuelta electoral}

Los resultados de la segunda vuelta electoral provocaron un conjunto de reacciones en toda la opinión pública. Por un lado, Ollanta Humala Tasso, quien era vinculado desde el 2006 con el gobierno autoritario del venezolano Hugo Chávez Frías, era simpatizante público del régimen de Juan Velasco Alvarado y además tenía un proceso archivado por violación de derechos humanos de su etapa como militar bajo el seudónimo de "Capitán Carlos". Por otro lado, Keiko Fujimori Higuchi, hija del hoy condenado por delitos considerados internacionalmente de lesa humanidad, el ex presidente Alberto Fujimori Fujimori, acompañada además de muchos de sus operadores políticos como la ex congresista Martha Chávez y ex ministros del régimen como José Chlimper, Alejandro Aguinaga y Carlos Trelles.

Sin saberlo, el Nobel de Literatura, Mario Vargas Llosa había vaticinado dicho escenario de segunda vuelta. En declaraciones a América Televisión manifestó: "No va 
ocurrir, me niego a creer que mis compatriotas van a ser tan insensatos de ponernos en la disyuntiva de elegir entre el sida y el cáncer terminal, que es lo que serían Humala y Keiko Fujimori”(Diario Gestión, 2009).

El país quedó polarizado políticamente. Sectores políticos liberales tradicionales y medios de comunicación conservadores, gremios empresariales, un conjunto de líderes de opinión como el economista Hernando De Soto y ex candidatos como Pedro Pablo Kuczynski tomaron partido por Keiko Fujimori. Mientras que un sector liberal secundado por Mario Vargas Llosa, ex candidatos como Alejandro Toledo y una mayoría de movimientos regionales y organizaciones de la sociedad civil como la Coordinadora Nacional de Derechos Humanos - CNDDHH tomaron partido por Ollanta Humala o contra Fujimori.

Luego de un sinnúmero de polémicas, acaloradosdebates, cuestionamientos de uno y otro lado y una de las contiendas más intensas de los últimos años, el domingo 5 de junio de 2011 se realizó la segunda vuelta electoral que dio como ganador a Ollanta Humala de Gana Perú con casi medio millón de votos por delante de Keiko Fujimori de Fuerza 2011 (ONPE, 2011):

Tabla 2.2.2 Resultados elecciones generales del Perú 2011 - Segunda vuelta

\begin{tabular}{|l|c|c|c|}
\hline \multicolumn{1}{|c|}{ Organización política } & Votos & $\begin{array}{c}\% \text { Votos } \\
\text { válidos }\end{array}$ & $\begin{array}{c}\% \text { Votos } \\
\text { emitidos }\end{array}$ \\
\hline Ollanta Humala - Alianza Gana Perú & 7937704 & $51,45 \%$ & $48,21 \%$ \\
\hline Keiko Fujimori - Fuerza 2011 & 7490647 & $48,55 \%$ & $45,49 \%$ \\
\hline
\end{tabular}

Fuente: Oficina Nacional de Procesos Electorales - ONPE (2011)

Tras analizar los resultados electorales del 2011, el experto en temas de descentralización, Javier Azpur manifestó (Diario La República, 2011): “La votación en el sur, centro y oriente lo que hace es repetir el mismo mapa social y político del 2006, con lo cual se reafirma una demanda de inclusión y mejor redistribución de la riqueza".

\subsection{Los tres programas de Gana Perú}


La política requiere de consensos y abrir su espectro político en determinados momentos de un proceso electoral. En el caso del proceso que llevó a la presidencia a Humala, el plan primigenio "La gran transformación" obtuvo un respaldo de un tercio del país en la primera vuelta, sin embargo, para la segunda parte de la contienda sus asesores consideraron necesario realizar dos documentos adicionales. El documento "La hoja de ruta" convocó a un conjunto de profesionales independientes y del Partido Perú Posible del ex presidente Alejandro Toledo, su fin era esclarecer un conjunto de dudas generadas desde la opinión pública sobre el rol del Estado en actividades estratégicas. Finalmente, con el compromiso público "Juramento por la democracia" se trató de generar un manifiesto público con compromisos concretos como respetar los derechos humanos, mantener el orden constitucional y respetar la propiedad privada en el cual se sumaron personajes de la talla de Mario Vargas Llosa, Nobel de Literatura 2010. Estos tres documentos trataron de ser puestos en cuestión por una parte de la prensa al ser señalados "Los tres programas de Humala" y así se deslizó que no era claro con cuál de todos gobernaría de ganar el proceso electoral.

\section{- La gran transformación}

El Plan de Gobierno 2011-2016 oficial de Gana Perú constó de 197 páginas (44 en versión resumida). Presentado ante el Jurado Nacional de Elecciones (JNE), fue con el que Humala participó en la primera vuelta en las Elecciones generales del 2011 y con el que logró el 31,72\% de los votos emitidos válidos. Este plan generó un conjunto de suspicacias en determinados sectores empresariales, medios de comunicación y líderes de opinión básicamente por ser señalado de "estatista" y tener propuestas de cambios estructurales como cambiar la constitución vigente y la participación del Estado en actividades estratégicas y productivas.

A continuación, un extracto de la "Propuesta Programática: Afirmar la Nación, Transformar el Estado" en 10 puntos (Ciudadanos por el Cambio, 2011):

1. Renovación política democrática. Una profunda renovación de la política que exprese a una sociedad plural, multicultural y pluriétnica, como base para construir un país más justo. Esta renovación se plasmará en una Nueva 
Constitución que sirva como herramienta para la construcción del Estado Nacional, diseñando una democracia donde participen y se sientan representados todas y todos los ciudadanos y pueblos del Perú.

2. Economía nacional de mercado. Un nuevo modelo de desarrollo de economía nacional de mercado, equitativo, incluyente y sostenible, que desarrolle nuestros mercados internos para integrarnos como país y articularnos competitivamente al mundo. En este marco, proponemos una política agraria de soberanía y seguridad alimentaria que permita la adecuada nutrición de los peruanos. Promoveremos para que esto sea posible una reforma tributaria democrática, donde paguen más los que más ganan y tienen. Apoyaremos, asimismo, las inversiones, nacionales o extranjeras, que respeten los derechos de los trabajadores, el medio ambiente y paguen sus impuestos.

3. Erradicación de la corrupción. El combate a fondo contra la corrupción que no es solo un problema de conductas sino también de identidad con el Perú y su destino. La corrupción corroe a las instituciones y se ha convertido en una forma de gobierno para defender y promover intereses privados. Erradicar este mal nos permitirá concretar la promesa de la vida peruana, de un porvenir con libertad y bienestar.

4. Recuperar soberanía sobre los recursos de la nación. La defensa de la soberanía nacional, de nuestro territorio y de nuestros recursos naturales, para que sirvan al desarrollo del Perú y no solo de las grandes empresas. En especial, nos comprometemos a una política de soberanía energética que recupere para el Estado el poder de las decisiones fundamentales en el negocio gasífero. Asimismo, a una respuesta consistente al cambio climático que se convierta en una política de Estado de largo plazo.

5. Descentralización con participación. Una descentralización que haga confluir el gobierno local y regional con el desarrollo territorial. Para ello promoveremos regiones transversales que sean espacios viables política y económicamente y un efectivo contrapeso al centralismo limeño.

6. Trabajo y pensiones dignas. La promoción del emprendimiento y el trabajo decente para los peruanos que labran el futuro desde todos los rincones de la patria, así como una pensión digna para una vejez sin sobresaltos. 
7. Educación y salud para todos. Sistemas universales, gratuitos y de calidad, en educación y salud, a los cuales tengan acceso todos los peruanos sin discriminación alguna por ingresos o condición social. Nos comprometemos, especialmente, a llevar adelante una revolución educativa que forme personas y ciudadanos con capacidades para producir bienestar. Reconoceremos, asimismo, los derechos de los pueblos indígenas y sus territorios ancestrales.

8. Vida segura. Una política integral de seguridad ciudadana para que todos puedan tener una vida tranquila promoviendo la participación de la población y potenciando la eficiencia de la Policía Nacional. Combatiremos a la delincuencia organizada, en especial al narcotráfico y al terrorismo, que se ciernen como amenazas sobre el Perú.

9. Derechos humanos y paz social. La promoción del diálogo y no de la represión para la canalización de la protesta social que permita alcanzar soluciones compartidas, consensuadas y duraderas, con pleno respeto a los derechos humanos y el objetivo de una paz social de largo plazo.

10. Integración regional y globalización solidaria. Convertir al Perú en un promotor del proceso de integración de América Latina, apoyando la Comunidad Andina, Mercosur y Unasur. Para ello, revisaremos todos los tratados de libre comercio que se opongan al ejercicio de nuestra voluntad soberana. En esta perspectiva pugnaremos por una globalización solidaria, que apoye el ejercicio de los derechos humanos, el multilateralismo, el respeto a la legalidad internacional y el buen uso de los recursos del planeta.

\section{- La hoja de ruta}

Este documento de sólo siete páginas es el que Gana Perú presenta a la opinión pública luego de la primera vuelta con el fin de alejarse del posicionamiento "radical" del programa primigenio y de ampliar su espectro político a un conjunto de profesionales, técnicos y nuevos aliados de otras tiendas políticas, entre ellos miembros del equipo técnico del ex presidente Toledo, además de recibir el respaldo público de Alianza por el Progreso de César Acuña, Acción Popular, Fuerza Social y otros sectores de la izquierda que no lo acompañaron desde el inicio como el Partido Comunista del Perú - Patria Roja y el Movimiento Nueva Izquierda - MNI, 
entre otros. Básicamente el documento enumera sus propuestas en materia social, económica y de reforma de Estado, en todas de las cuales se comprometía a respetar el marco jurídico y la independencia de poderes:

Lineamientos centrales de política económica y social para un gobierno de concertación nacional:

El compromiso con el pueblo peruano firmado por Ollanta Humala establece que la transformación que el país requiere se hará de manera gradual y persistente

- En el marco del Estado de Derecho

- El respeto absoluto a la división de poderes del Estado

- Honrando todos los honrando del Estado

- Restableciendo el principio de la ética pública, combatiendo la corrupción y eldespilfarro del dinero del Estado (El Comercio, 2011).

\section{- Juramento por la democracia}

Por último, a menos de un mes de la segunda vuelta electoral, Ollanta Humala firma un manifiesto público donde se compromete en el respeto a los derechos humanos, la independencia de los poderes del Estado y a mantener el orden constitucional, tres de los principales cuestionamientos que tenía pendiente de esclarecer a un sector que aún no había apoyado su candidatura sin ambigüedades. Así logra finalmente el apoyo público del Nobel de Literatura 2010, Mario Vargas Llosa, quien además graba un video de apoyo que es luego utilizado como spot de campaña.

En este documento final, Humala jura por doce puntos clave:

1. Proclamo que no me quedaré ni un minuto más de los 5 años, que dura el período presidencial. Asumo el compromiso de no hacer ni intentar ningún cambio constitucional que permita la reelección.

2. Manifiesto que respetaré la independencia y los fueros de los otros poderes del Estado. 
3. Me comprometo a que la libertad de expresión será respetada, protegida y estimulada. Que la libertad de prensa no solo será respetada y valorada sino será decididamente defendida.

4. Proclamo que cumpliré con los cambios ofrecidos para lograr una distribución más justa de los recursos económicos del Perú, y para una mayor inclusión económica, social, étnica, geográfica y cultural de todos los peruanos, especialmente de quienes se encuentran en pobreza o extrema pobreza.

5. Declaro que los cambios para una distribución más justa de recursos y para una menor exclusión, se harán respetando siempre los procesos propios del estado de derecho, y teniendo siempre presente la importancia de no arriesgar sino de estimular el sostenido crecimiento económico que vive el país.

6. Respetaré los derechos humanos de todos, y no permitiré ningún tipo de influencia política en las investigaciones que sobre la violación de estos derechos estén en curso o se abran en el futuro.

7. Me comprometo a que la lucha contra todo caso de corrupción que se haya cometido en el pasado o que pudiera cometerse en mi gobierno, será una prioridad para mí, creando y fortaleciendo los instrumentos necesarios para ello.

8. Daré prioridad a una política internacional de buenas relaciones con todos los países de la región, y ante cualquier diferencia o controversia apelaremos solo a las vías de la diplomacia y el derecho internacional.

9. Será prioridad de mi gobierno luchar eficazmente contra la inseguridad ciudadana, el terrorismo, el narcotráfico y el crimen organizado.

10. Proclamo que los ministros de Defensa y del Interior serán civiles, en respeto al principio del control civil democrático sobre las fuerzas de seguridad.

11. Nos empeñaremos en prevenir y solucionar los conflictos sociales. Nuestro gobierno garantizará las inversiones y la explotación de recursos naturales, garantizando a la vez el respeto a los derechos y libertades de los pueblos indígenas y de las poblaciones locales, junto con los estándares de medio ambiente que no solo demandan la ley nacional y los convenios internacionales sino, sobre todo, las generaciones futuras. 
12. En mi gobierno primarán los principios de no discriminación y de igualdad de oportunidades. Nadie será menos en la Patria de todos y nadie deberá sentir que no tuvo la oportunidad y la protección que su país debió brindarle.

Juro ante Dios, ante la Historia y ante mi pueblo que cumpliré estas promesas y seré un Presidente que solo actúa dentro de la Constitución y el Estado de derecho. Tienen mi palabra. (Diario La República, 2011).

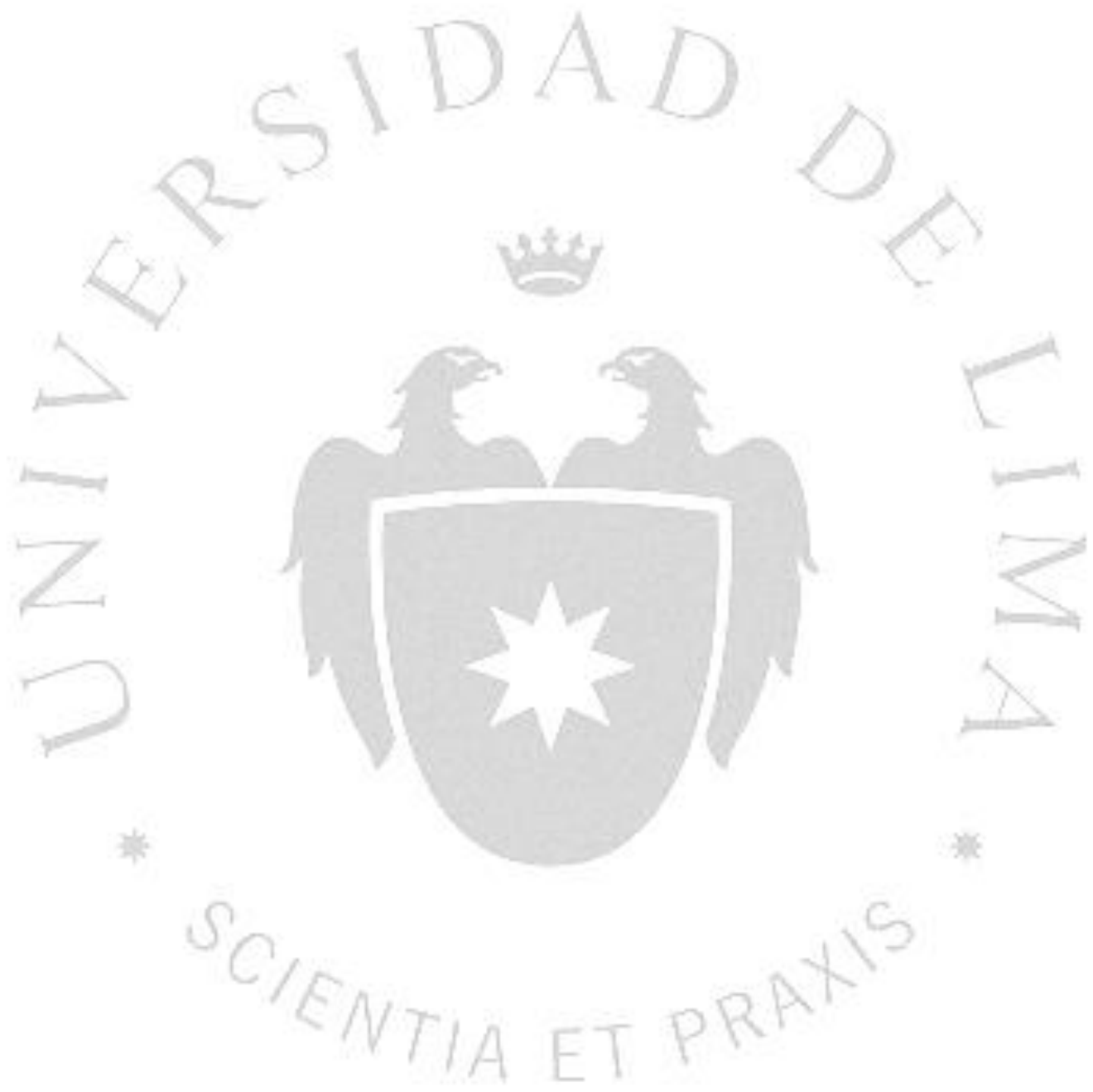




\section{CAPÍTULO III:MARCO TEÓRICO}

En esta etapa de nuestro estudio plantearemos la base teórica que sustenta nuestras variables y enfoques a lo largo del texto. Hemos planteado tres planos: el conceptual, sobre la inclusión social como concepto; político, la base teórica que da respuesta a los procesos que se generan en torno al debate sobre la inclusiónyel mediático, vinculado a la priorización de temáticas desde los medios de comunicación.

\subsection{Plano conceptual}

Hablar de inclusión social implica que aún en el mundo en pleno siglo XXI subsiste algún tipo de exclusión, pues existen grupos humanos, minorías étnicas y comunidades que no pueden hacer pleno uso de sus derechos. Esta es una realidad que se mantiene para las grandes mayorías de la humanidad, limitando su accesibilidad a servicios básicos, interacción participativa, ejercicio de ciudadanía y, en concreto, sus posibilidades de desarrollo.

Se reconoce a Amartya Sen (1998), Premio Nobel de Economía 1998, como uno de los intelectuales más reconocidos en la materia porque que puso en el debate global el “Desarrollo como Libertad". Este debía ser más que las cifras y el aumento del Producto Bruto Interno (PBI), sino que estaba vinculado al reconocimiento de las libertades de los ciudadanos y ciudadanas en la sociedad, donde se garanticen la atención de necesidades básicas, libertad para expresarse y sobre todo con participación activa de los procesos que vivan las naciones (como el crecimiento económico). Es decir, se empieza a concebir al sujeto como diverso. Con agencia y autonomía para decidir.

A nivel mundial, la inclusión social se concibe como individual y colectiva, permitiendo a los individuos y a los grupos participar activamente en la sociedad, ejercer sus derechos fundamentales y mantener una calidad de vida digna. En el marco de la cooperación estratégica de la Unión Europea (2003) se define como un proceso que gira en torno a la unión de sus países miembros para "fortalecer la lucha contra factores (educativos, económicos, sanitarios, laborales, etc.) que sean consecuencia de la pobreza y la exclusión”.De su“'Informe conjunto sobre la inclusión social”se puede 
concluir que sus estados miembros se centran en el acceso a los derechos (en particular los sociales) como principio básico para respaldar el desarrollo de sus políticas y programas.

Plantear un estudio sobre la inclusión social nos invita a indagar también sobre la exclusión.Hilary Silver (2003), una de las más grandes escritoras sobre la exclusión social en el mundo, sostiene que es 'multidimensional' (que abarca colectivos y recursos individuales), dinámica (con múltiples exclusiones), relacional (implica negación a participar), activa y con relación al contexto en que se da. Martinelli (2009)coincide en que es 'multidimensional', porque se refiere no solo a niveles insuficientes de consumo presente, sino también a las malas condiciones de salud, poca educación de los hijos y otras circunstancias que afectan a las familias pobres y desembocan en bajos ingresos e insuficiente consumo en el futuro.

Uno de los esfuerzos de políticas gubernamentales más universales son los programas sociales.Los sistemas de protección social evitan que las personas que se vean privadas momentánea o permanente de las rentas de trabajo, caigan en la pobreza y por ende, se conviertan en excluidos. Los estados que tienen un gasto social per cápita mayor tienen menos riesgo de caer en pobreza y viceversa. Martinelli (2009) señala que lo central de estas políticas sociales es que abonan a romper con la transmisión generacional de la pobreza. Además recalca que para que los programas de ayuda social tengan éxito deben estar bien focalizados, es decir, que se beneficien las personas que realmente lo necesiten.

Cuando hablamos de inclusión social y derechos, es importante también hablar de ciudadanía. Sobre su definición, el sociólogo peruanoSinesio López (1997) señala que es ciudadano aquella persona con derechos reconocidos por el Estado y que tiene responsabilidades con respecto a la comunidad a la que pertenece.El concepto de ciudadanía alude fundamentalmente a dos aspectos: pertenencia y reconocimiento. El primero se refiere a la pertenencia a una comunidad política y la segunda al reconocimiento al interior de dicha comunidad, de ser sujeto de derechos y 
responsabilidades, además de titulares de poder. El ejercicio de derechos por tanto se encuentra limitado por el marco de responsabilidad que permite el funcionamiento de la comunidad política y la armonía de las relaciones entre los ciudadanos.

En el 2009 PNUD publicó el Informe sobre Desarrollo Humano Perú, Por una densidad del Estado al servicio de la gente (PNUD, 2010). Dicho documento elabora un índice de "densidad estatal" y lo mide a partir de 5 indicadores base como la tasa de asistencia a la escuela, número de médicos por habitantes, el porcentaje de viviendas con acceso a servicios básicos como electricidad, agua y desagüe y cuanta población posee partida de nacimiento y documento de identidad (DNI). Este estudio invita a una reflexión sobre la presencia del Estado alrededor del territorial nacional del Perú, acerca de su precariedad institucional no sólo para garantizar los servicios básicos, sino también para redistribuirlos de manera equitativa y con calidad. En ese sentido, el informe demanda una mayor presencia Estado a través de políticas sociales que más que beneficios, garanticen derechos ciudadanos.

\subsection{Plano político}

Ernesto Laclau y Mouffe en su libro "Hegemonía y estrategia socialista" plantean que la política es una lucha constante por ganar los sentidos comunes de las personas. Dicho fenómeno se visibiliza a través del discurso político el cual no debe ser lo que se dice de intereses ya conocidos o de acceso universal a nivel de la economía o de la sociedad, porque no deben sólo expresar sino construirle sentido a las cosas, pues insisten en que la política es la lucha por el sentido común(Laclau y Mouffe, 2005).

Aquella propuesta política que es capaz de generar o encarnar una idea de consenso social es aquella que convoca no sólo a una la inmensa mayoría de la ciudadanía, sino que además fija las condiciones y temáticas del debate ante quienes se enfrentan. Bajo esta lógica podemos hacer el símil con la propuesta que representó Gana Perú a través de Ollanta Humala en el marco de las elecciones del 2011, pues encarnó una propuesta de cambio con el consenso social de la "inclusión social" y arrinconó a sus adversarios 
políticos para que discutan también sobre el tema y sus propuestas electorales que planteaba.

Ernesto Laclau también plantea el concepto de "significante vacío" que son elementos discursivos privilegiados, de naturaleza ambigua, polisémicos y con el potencial para hegemonizar un espacio político. Ejemplos prácticos sobre los significantes vacíos podrían ser los significantes vacíos como libertad, democracia y justicia.

Bajo este criterio, planteamos que el concepto de "inclusión social" reúne todas las características para ser considerado un "significante vacío", pues es un concepto que tiene una privilegiada legitimidad, por sí sólo no tiene significado concreto y puede ser llenado de una significación en el plano político.

Por otro lado, Ernesto Laclau en su libro "La razón populista" (2005) plantea además la lógica de un "significante flotante", el cual puede superponerse al mismo "significante vacío", por ejemplo, el concepto de libertad para un liberal está mucho más vinculada a los derechos a la libertad de expresión y libertad de mercado, mientras que para un social demócrata, probablemente esté más relacionado a la libertad vinculada a la igualdad de oportunidades y de servicios públicos. En síntesis, un significante flotante es aquel significante vacío al que se le confiere una carga de significación.

Vinculando este último concepto al marco de las elecciones del 2011 en el Perú, planteamos que un ejemplo de significante flotante es el propio concepto de inclusión social, pues en medio de la campaña electoral la propuesta de Humala le confirió la significación de redistribución de la riqueza, programas sociales, reformas laborales, entre otras, y -como mencionamos antes- también ha sido un significante vacío, pues es un concepto con consenso social y respaldado por todas las fuerzas del espectro político.

Conceptos como "inclusión social" son legítimos per se. Sin embargo, si estos significantes están demasiado abiertos tienen el riesgo de estar también muy vacíos, porque tiene demasiadas posibilidades de significación. Si bien esto permite convocar a 
una mayor parte de la ciudadanía, luego se puede tener un número importante de hipotecas.

\subsection{Plano mediático}

Hoy en día con el desarrollo tecnológico y una 'Aldea global' (McLuhan, 1964)cada vez más universal por efectos de la globalización, los medios de comunicación son necesarios para la 'legitimación' de gobernantes o autoridades, pues por ejemplo, actualmente no es posible ganar una elección si los candidatos no aparecen en los medios de comunicación. Además estos pueden ejercer cierta presión para que las promesas de campaña se cumplan, ya que fueron publicadas masivamente, siendo así, la comunicación, un agente orientador de la sociedad, mediante la identificación de sus conflictos.

Para Canell (2006) no hay política sin medios de comunicación, ya que en la medida que se han desarrollado y expandido -desde el siglo XX- han sido protagonistas de la historia política mundial, lo que los ha hecho merecedores de ser llamados agentes o grupos de presión que influyen y ejercen un importante poder con relación a las instituciones políticas.

Por otro lado, el autor Alexander Meiklejohn (1961) plantea la importancia de los medios como vigilantes de la democracia. Nos dice que los medios tienen dos roles vinculados a la libertad de expresión en una democracia. Otorgar la información necesaria y tener una postura crítica, pues los medios pueden ser vigilantes ciudadanos que evalúan el desempeño tanto de los políticos como el de las instituciones.

El internacionalista Farid Kahhatt (América Económica, 2012)hace un comparativo sobre este rol de los medios poniendo como ejemplo los peruanos y comenta que los medios de comunicación en el Perú responden a la voluntad de sus propietarios: si estos en su gran mayoría deciden respaldar una candidatura a través de ellos, tienen derecho de hacerlo.

Además plantea como ejemplo, un caso en EEUU “¿acaso el "New York Times” no respaldó en 2008 la candidatura presidencial de Barak Obama del mismo modo en que 
el "Wall Street Journal" respaldó la candidatura presidencial de John McCain? La respuesta obvia es sí, pero con una atingencia que suelen olvidar quienes creen que el periodismo es un sucedáneo del "Vale Todo"". Kahhat critica que esos diarios respaldaron dichas candidaturas por medio de sus páginas editoriales y de opinión, no a través de su cobertura informativa, es decir, no ocultaron información porque pudiera favorecer al candidato contrario a sus preferencias ni la tergiversaron.

Gracias a su poder intangible, son los propios medios de comunicación y de prensa los que imponen y jerarquizan los contenidos de sus canales, páginas, emisoras y otros soportes. De esta manera, los encargados de los también llamados mass media, son quienes establecen la relevancia de algunos eventos en particular y reducen otros casi hasta el anonimato, decir tiene prioridades. Este proceso de jerarquización y seccionamiento de noticias es conocido con el nombre de "Agenda Setting" o “Establecimiento de la Agenda”.McCombs (1972)plantea esta influencia como el Establecimiento de la agenda o "agenda-setting”, pues los medios tienen impacto en la opinión pública al determinar qué temas tienen interés informativo o no y el espacio que le asignan a estos.

Los núcleos informativos con más prestigio serán los primeros en determinar la agenda, por ello se colocan en la cabeza de la pirámide. Luego otros no tan relevantes, ubicados en el cuerpo de la pirámide, imitarán dicha jerarquización y así el orden de importancia de noticias; por ejemplo, las noticias, entrevistas, investigaciones, etc. de El Comercio y La República, serán en gran medida las que marquen la agenda a nivel de prensa escrita.

Dittus (2006) señala un componente adicional, recoge la teoría de Samantha NoelleNeumann (1996)“La Espiral del Silencio" que plantea que el ser humano biológicamente quiere ser aceptado y teme el rechazo de los demás, es decir, la autoprotección social que reflejaría el denominado "miedo al aislamiento" es sólo una reacción institucional, apoyada por los medios de comunicación como recreadores simbólicos de la realidad y por las emociones que actúan como dispositivos de control social. 


\section{CAPÍTULO IV:RESULTADOS}

Comenzamos nuestro estudio sustentando el uso de nuestras variables. En este trabajo de investigación no sólo hemos considerado como variables las que están vinculadas naturalmente al concepto tradicional de inclusión social como son los programas sociales, servicios públicos o lucha contra la pobreza, sino además hemos incorporado nuevos elementos como redistribución de la riqueza, reformas tributarias en minería, reformas laborales, protección del ambiente, lucha contra la corrupción, prevención de conflictos sociales, descentralización y cumplimiento de promesas de campaña.

Partimos por identificar el concepto de inclusión social con lo que Ernesto Laclau llamó un "significante vacío" (Laclau, 1985), es decir, aquella imagen o palabra sin significado concreto pero que funciona como un todo y goza de una privilegiadalegitimidad, por ejemplo, significantes como justicia, libertad o democracia, todos claves en determinados contextos políticos. Bajo esta lógica, inclusión social es y será siempre un término de indiscutible consenso en el que miembros de diversas tiendas políticas por muy diferentes que estas sean como el Partido Popular Cristino PPC, APRA, Fuerza Popular o alguna agrupación de izquierda no podrían poner en cuestión.

Es allí donde en el marco de las elecciones generales 2011-2016 la propuesta política de Ollanta Humala convierte el concepto de inclusión social además en un "significante flotante" (Laclau y Mouffe, 2005), es decir, le confiere una carga de significación concreta vinculándolo a toda su oferta electoral o propuestas de campaña como redistribución de la riqueza, reformas tributarias en la minería y, en general, el impulso de un rol más protagónico del Estado. Entonces, en dicho contexto la inclusión social ya no sólo significaba "incluir a los excluidos" sino además era sinónimo de un impuesto a 
las sobreganancias mineras, recuperación del país de manos de los corruptos, garantía de diálogo ante conflictos sociales, ordenamiento territorial, eliminación de los regímenes CAS y las services $\mathrm{y}$, en resumen, de redistribuir el tan comentado crecimiento económico para todos los peruanos y peruanas, paradójicamente muy bien sintetizado en el eslogan de campaña de Gana Perú: "El Perú para todos". He allí la pertinencia en considerar como variables a estos nuevos elementos en nuestro análisis.

Para esta investigación hemos analizado 468 noticias, es decir, el total del universo de lo que los diarios El Comercio y La República publicaron sobre las políticas de inclusión social (nuestras variables) impulsadas durante los 100 primeros y simbólicos días del Gobierno de Humala. Como hemos mencionado antes en el sustento de nuestra propuesta metodológica, nuestro principal criterio ha sido la frecuencia de publicación de nuestras variables y un análisis tanto de forma como de contenido.

\subsection{Resultados del análisis de forma}

Partiremos por analizar la forma. Ello incluye la sección del diario en donde las noticias fueron publicadas, quién o qué aparece cuando hablamos de inclusión social (fotografía), a quiénes se les da la palabra (fuente) y, para cerrar esta parte, la ubicación (página) y extensión (tamaño) de dichas noticias.

\subsubsection{Sección de publicación}

¿En qué sección se ubican las noticias sobre inclusión social?

Estos son los resultados de El Comercio y La República acerca de la sección en la que hay una mayor frecuencia de publicación de noticias sobre políticas de inclusión social:

Figura 4.1.1.1

Frecuencia de noticias sobre políticas de inclusión social por sección (\%)

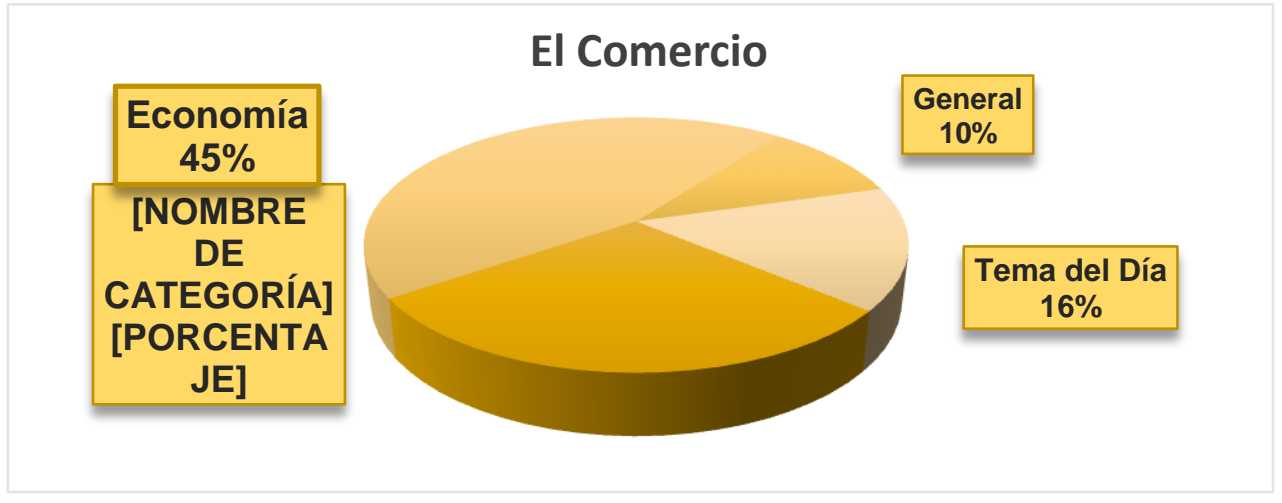


Figura 4.1.1.2

Frecuencia de noticias sobre políticas de inclusión social por sección (\%)

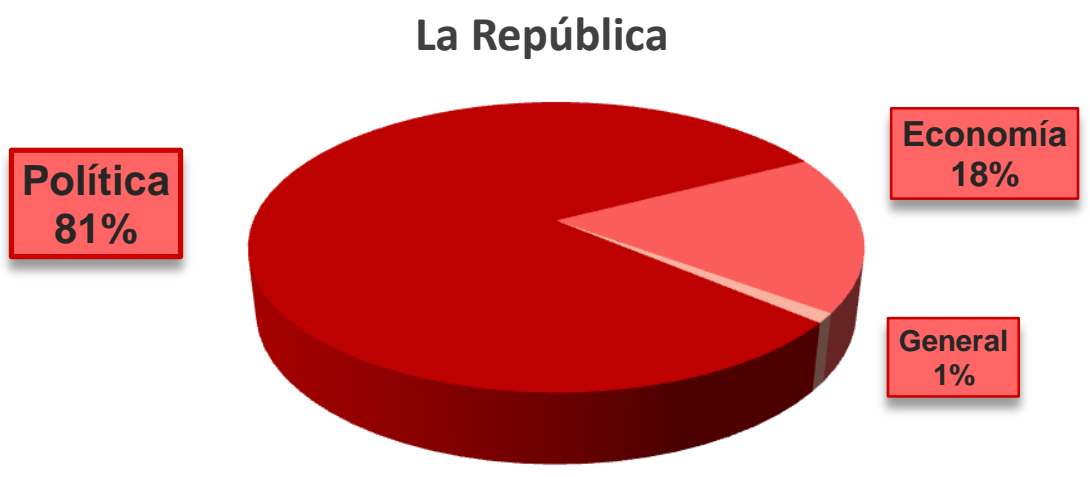

Fuente: Gráfica de elaboración propia

El Comercio presenta una mayor frecuencia de publicación en la sección Economía (45\%) y en segundo término en la de Política (36\%). Mientras tanto en La República sucede todo lo contrario, la frecuencia de publicación es mucho mayor en la sección Política $(81 \%)$ y con una frecuencia menor en Economía (18\%).

A partir de estas marcadas diferencias señalamos que para El Comercio la temática de la inclusión social está vinculada a la economía del país y es directamente proporcional al estímulo del crecimiento sostenido de esta. Ello demanda no sólo mantener un Producto Bruno Interno - PBI con cifras en azul sino también la vigencia del propio modelo económico. En su editorial titulado "Inclusión social, de la verdadera" el medio hace énfasis en que el modelo económico actual del Perú permitió que entre el 2002 y 2010 la pobreza en general se reduzca de $54 \%$ a $31 \%$, según el Banco Mundial (Diario El Comercio, 2012).

En contraste, para La República la inclusión social es una discusión de índole más política. En su editorial sobre el primer discurso presidencial cuando hace alusión a la 
inclusión manifiesta: "Hay que destacar que el premier anunció el logro de un acuerdo con las mineras para un gravamen a las sobreganancias, la aplicación de la Ley de Consulta Previa, una política ambiental responsable, la continuidad de la Carrera Magisterial, y un esfuerzo especial por lograr un ordenamiento territorial. También un combate implacable a la corrupción. (...) En suma, ahora contamos con letra y música para la transformación anunciada." (Diario La República, 2011). Si bien este diario no deja de destacar la importancia de lo económico y lo considera como una herramienta central para poder alcanzar dicha inclusión social, pero cuando se refiere al propio término prioriza el conjunto de compromisos de campaña en materia social y la voluntad política del Gobierno en cumplir con estos.

\subsubsection{Tipo fotografía usada para acompañar las noticias}

¿Qué o quiénes aparecen en las noticias sobre inclusión social?

En casi la totalidad del universo analizado en ambos diarios se presentan fotografías que acompañan las noticias sobre las políticas de inclusión social. A continuación mostramos los resultados de qué o quiénes son visibilizados en dichas imágenes.

Figura 4.1.2.1

Frecuencia de actores visibilizados en las fotografías (\%)

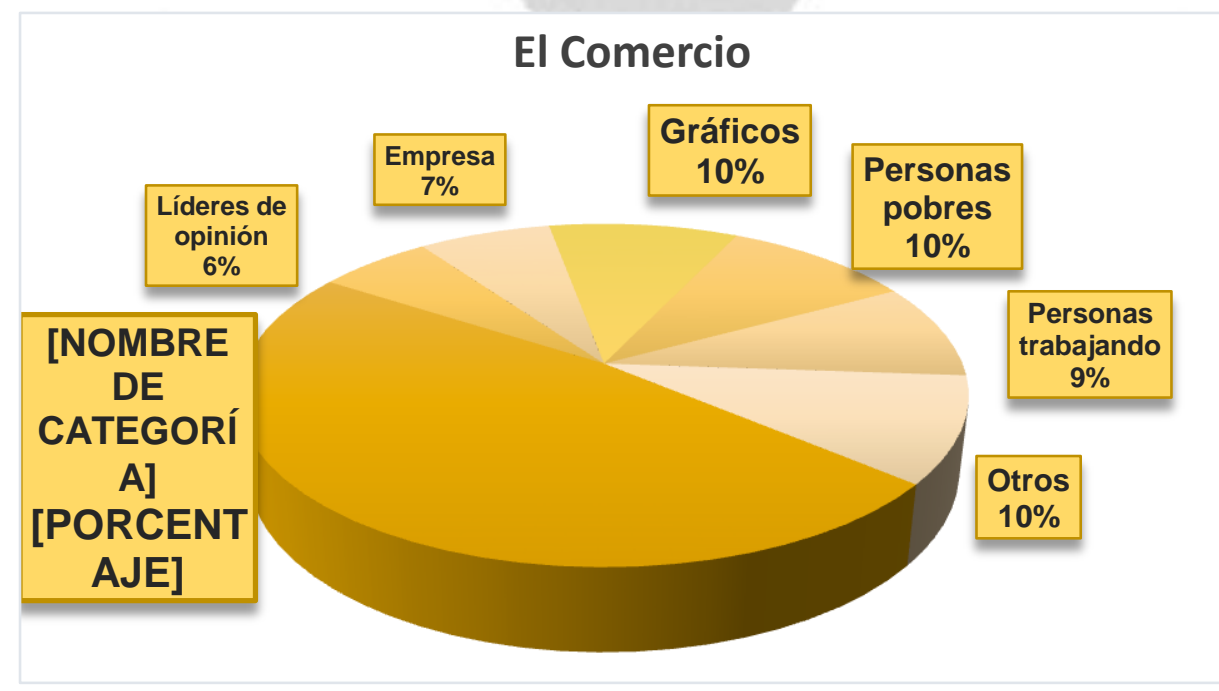

Fuente: Gráfica de elaboración propia 
Figura 4.1.2.2

Frecuencia de actores visibilizados en las fotografías (\%)

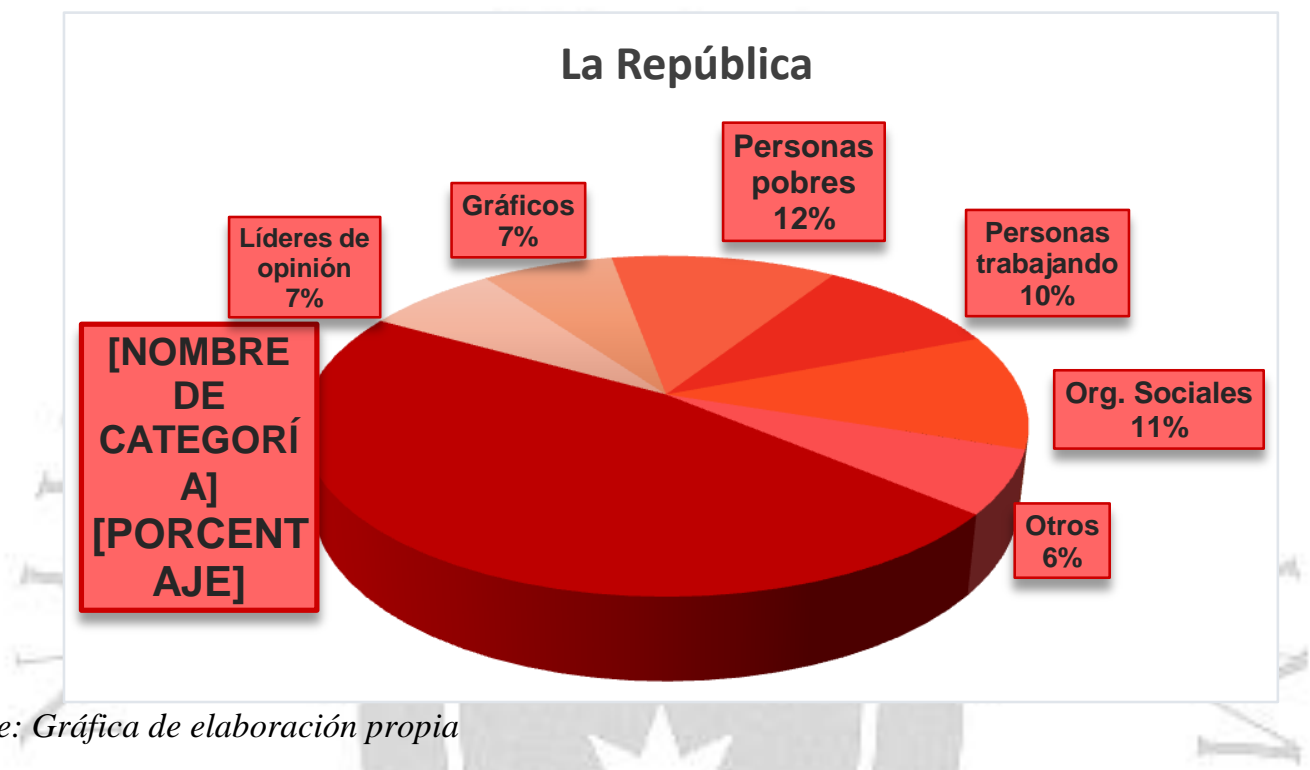

Tanto en El Comercio como en La República, la lista la lidera el Gobierno con $48 \%$ y $47 \%$ respectivamente. Estos resultados indican la correlación directa que existe entre las noticias sobre políticas de inclusión social y la imagen del Poder Ejecutivo a través del presidente y ministros. Es decir, más allá que la noticia tenga un enfoque positivo o crítico, ambos diarios visibilizan a "quienes serían los responsables de consolidar la inclusión social en el país".

Otra coincidencia que hallamos en ambos diarios es que muestran a Personas pobres $(10 \%)$ en las noticias sobre inclusión social. Tal vez consideran que una manera ilustrativa de graficar la temática es a partir de mostrar a quienes están siendo excluidos o en situación de vulnerabilidad como son las comunidades rurales, pueblos indígenas o ciudadanos que no tienen servicios públicos. En La República el segundo lugar también lo ocupa Organizaciones Sociales $(11 \%)$ que resaltan por los múltiples compromisos que en su momento asumió Ollanta Humala con dichas agrupaciones. Estas noticias suelen 
estar relacionadas a conflictos sociales, pero también a procesos de diálogo iniciados y a demandas que se impulsan desde las regiones.

En ambos diarios hay un tercer elemento en común, Personas trabajando (El Comercio 9\% y La República 10\%). A ello le damos una explicación similar a la de mostrar en las fotografías a ciudadanos pobres, porque las personas trabajando se convierten también en una manera gráfica de representar la inclusión social por la relación directa que tiene con el trabajo o el nivel de productividad que debe alcanzar un país para lograr una inclusión sostenida.

Sobre esto último, Robert Castel denomina una "relación salarial fordista" a la redistribución de la fuerza del trabajo y el salario bajo un marco legal justo que lo regula (Castel, 1995). Ello en la práctica funciona como una manera concreta de garantizar la inclusión social por la vía del trabajo.

\subsubsection{Fuentes de la noticia}

¿Quiénes hablan o a quiénes se les da la palabra?

En esta parte del estudio hemos identificado quienes son las principales fuentes en las noticias sobre las políticas de inclusión social, es decir, quienes son los interlocutores que estos medios consideran válidos y qué voces se visibilizan con una mayor frecuencia.

Figura 4.1.3.1

Frecuencia de actores visibilizados como fuentes (\%)

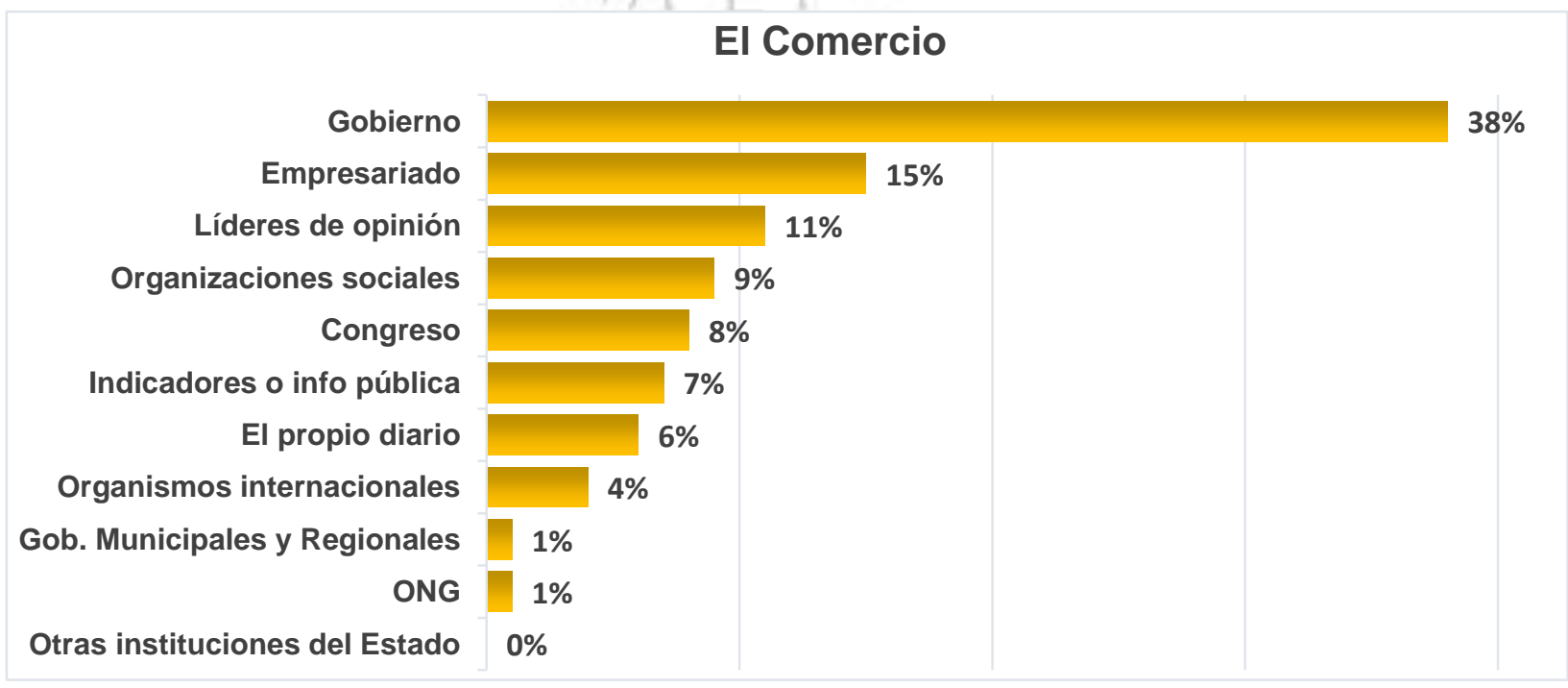


Figura 4.1.3.1

Frecuencia de actores visibilizados como fuentes (\%)

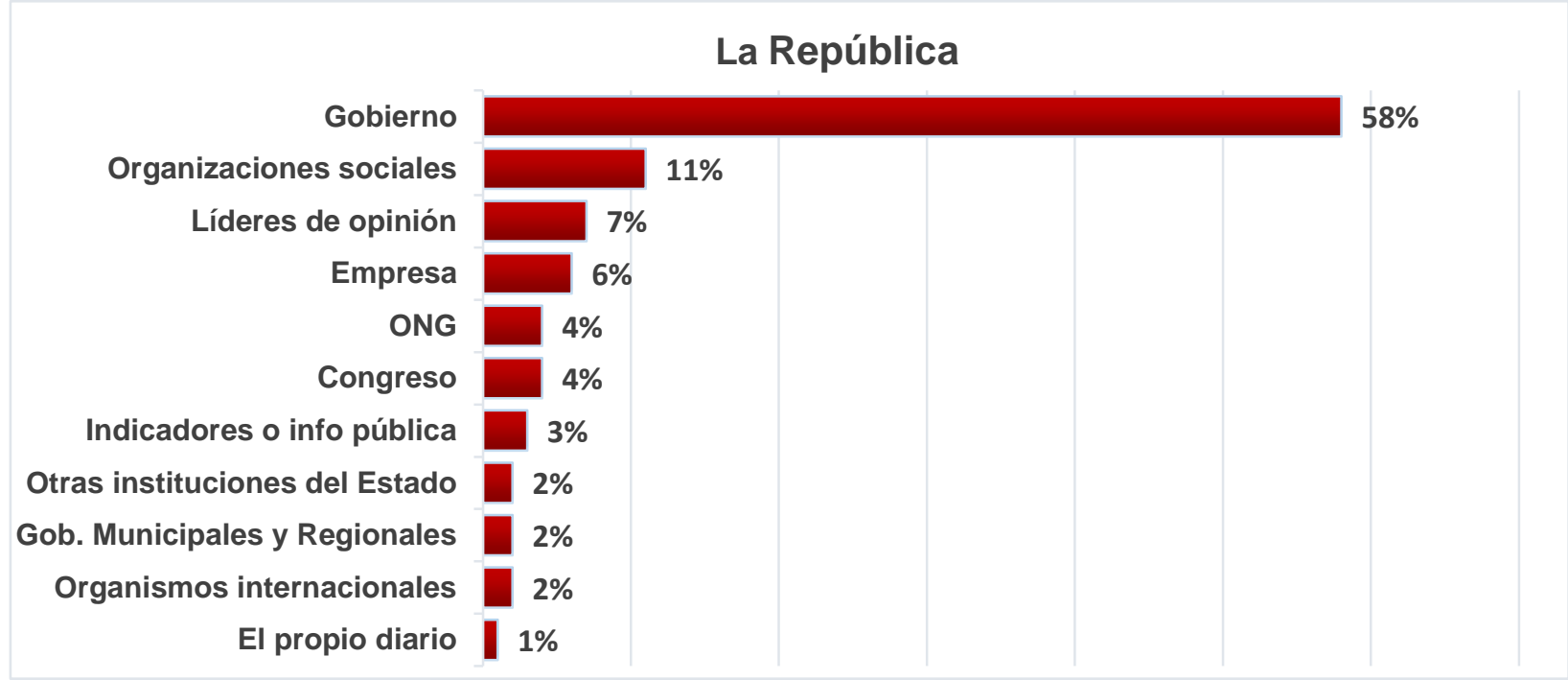

Fuente: Gráfica de elaboración propia

Los resultados nos indican por unanimidad que la principal fuente de las noticias vinculadas a políticas de inclusión social es el Gobierno (El Comercio 38\% y La República 58\%), porque al ser el mayor responsable de toma decisiones en materia social resulta el interlocutor más legítimo. Este resultado también está vinculado a que en ese momento el Gobierno de Humala acababa de iniciar su mandato y ambos medios de prensa iban realizando una suerte de monitoreo con el fin de ir informando sobre sus primeras decisiones, acciones y gestos políticos.

Sobre esta suerte de vigilancia mediática, el autor Alexander Meiklejohn plantea que los medios tienen dos roles vinculados a la libertad de expresión en una democracia. Otorgar la información necesaria y tener una postura crítica, pues los medios pueden ser vigilantes ciudadanos que evalúan el desempeño tanto de los políticos como el de las instituciones (Meiklejohn, 1961). 
Siguiendo con las coincidencias, dentro de los tres primeros lugares ambos diarios presentan como fuente frecuente a Líderes de opinión (El Comercio 11\% y La República 7\%). Ello quiere decir que personajes de la sociedad civil, técnicos, periodistas o ex autoridades son sumamente válidos para que los diarios fortalezcan sus posiciones con argumentos tanto con peso técnico como político o social. Es importante hacer énfasis en que justamente el propio diario es el que busca a determinado líder de opinión de acuerdo a su propio enfoque periodístico. Por ejemplo, si El Comercio quiere poner en cuestión el "Rol empresarial del Estado", lo más probable es que busque la opinión de algún técnico vinculado a los gremios empresariales que señale que el Estado no es un administrador, mientras que La República, probablemente recoja la opinión de algún político o técnico que argumente que sí es posible un rol más protagónico del Estado siempre que este sea más eficiente y sin corrupción.

Ahora vamos a las diferencias. El segundo lugar de fuente de información en las noticias sobre políticas de inclusión social para El Comercio es el Empresariado (15\%). Esta cifra nos indica que para El Comercio, luego del Gobierno, los interlocutores más válidos para discutir sobre inclusión social son los representantes de los gremios empresariales. Entre ellos destacan los directivos de la Confiep, Sociedad Nacional de Industrias - SNI y ADEX. Además claramente hay una correlación con la Figura 4.1.2.1 o "Sección de publicación" donde señalamos que economía es la sección de El Comercio con una mayor frecuencia de publicación de noticias sobre políticas de inclusión social.

Por otro lado, tenemos que para La República la segunda fuente más recogida es el de las Organizaciones sociales (11\%). Esto en gran medida responde a las propias promesas de campaña de Gana Perú y por ello la mayoría de esas temáticas estuvieron en agenda durante los 100 primeros días de Gobierno de Humala. Entre dichos temas estuvieron, por ejemplo, la Ley de Consulta Previa (con organizaciones sociales como AIDESEP o el Pacto de Unidad) o la Ley General del Trabajo (con centrales sindicales como la CGTP o la CUT). 


\subsubsection{Página y extensión de las noticias publicadas}

¿Qué relevancia les dan a las noticias sobre inclusión social?

Nuestro principal criterio de análisis es la frecuencia de publicación, sin embargo, en esta parte tuvimos en cuenta también criterios como la página (ubicación) y extensión (tamaño) de las noticias publicadas.

Para la página/ubicación, le dimos un puntaje del 1 al 20 según donde esté publicada cada noticia (a las de la Pág. 2 les dimos 20 pts. y a las Pág.20 les dimos 1 pt.). Luego este resultado fue dividido entre su extensión/tamaño (si, por ejemplo, obtuvo 20 pts. y su extensión es de $1 / 2$ hoja, el puntaje final será 10 pts.). Cabe recalcar que El Comercio presenta el tema de Economía como suplemento especializado, por eso, a las noticias sobre este tema ubicadas en su cuerpo principal les dimos puntaje extra (por 2).

Figura 4.1.4.1

Relevancia de las temáticas por ubicación (\%)

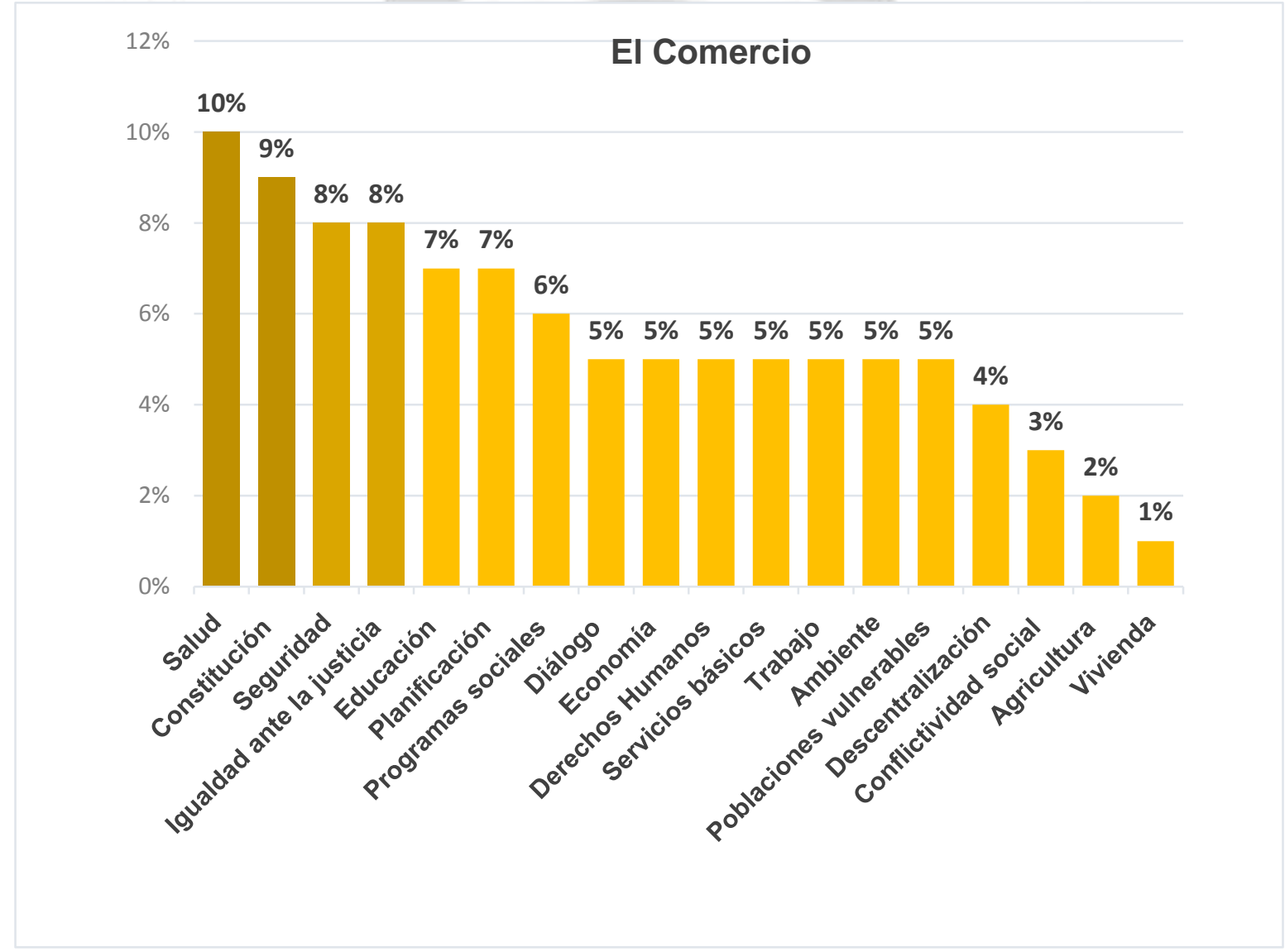

Fuente: Gráfica de elaboración propia 
Figura 4.1.4.2

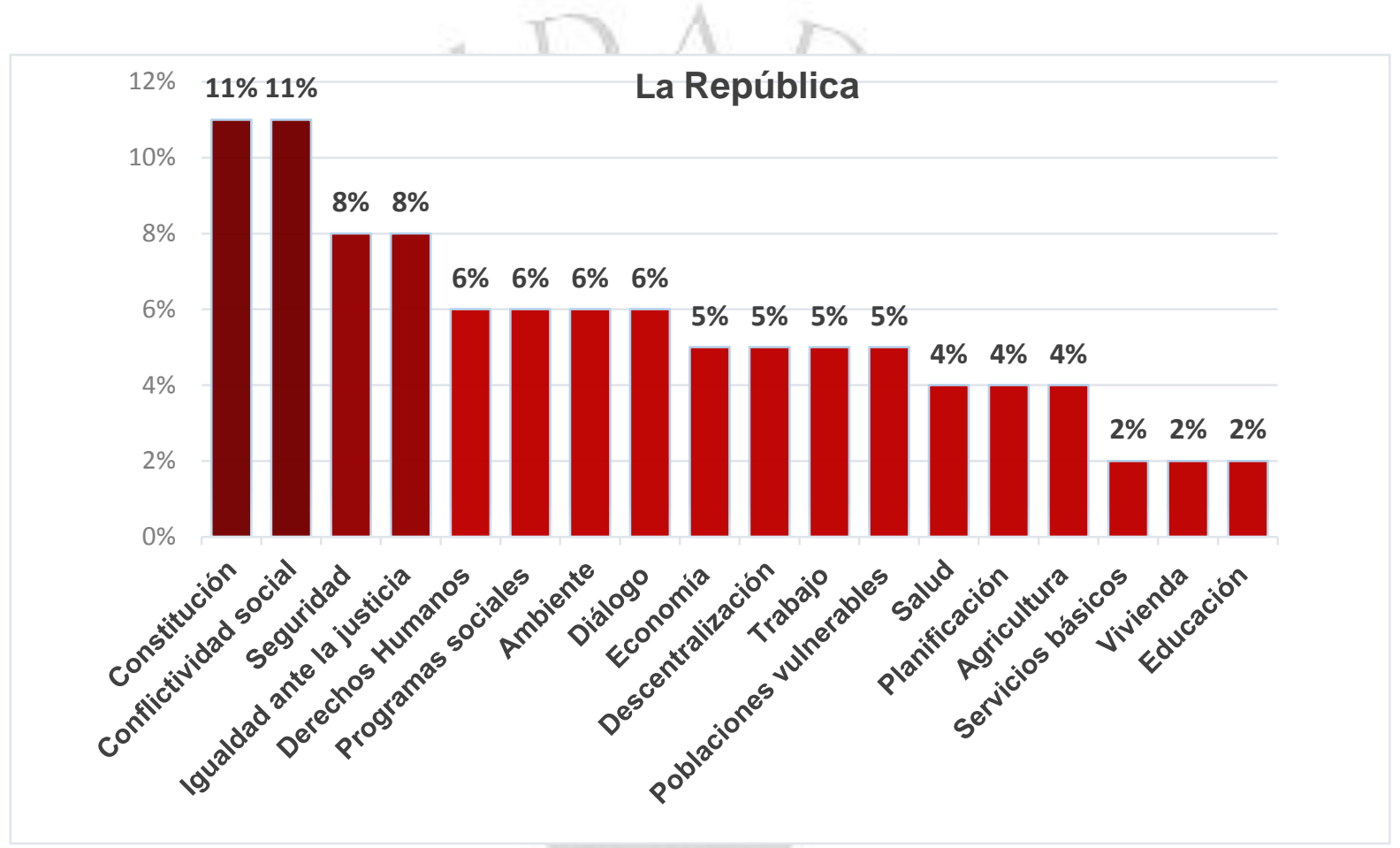

Relevancia de las temáticas por ubicación (\%)

Fuente: Gráfica de elaboración propia

Los primeros lugares de los resultados de El Comercio son Salud (10\%), Constitución (9\%), Igualdad ante la justicia (8\%) y Educación (8\%). Para La República esos resultados le corresponden a Constitución (11\%), Conflictividad social (11\%), Seguridad (8\%) e Igualdad ante la justicia (8\%).

Como se mencionó anteriormente, estos resultados no incluyen la frecuencia de publicación o la cantidad de veces que se publicó sobre el tema, sino su página/ubicación y su extensión/tamaño. Dicho eso, podemos señalar que temas como 
Salud (10\%) en El Comercio o Conflictividad social (11\%) en La República lideran los resultados tal vez porque son temas que por lo general demandan una extensión importante de texto (más de 1 página) para explicar los elementos que implican e incluso incluyen amplias infografías. Consideramos que es así que obtienen un alto puntaje en esta parte del estudio (tendencia que no necesariamente se repite en el número de veces que se publicó sobre dichos temas).

Pero vamos a enfocarnos en los resultados comunes en ambos diarios: Constitución (El Comercio 9\% y La República 11\%) e Igualdad ante la justicia(El Comercio 8\% y La República 8\%). Sobre el primero, podemos señalar que la reforma de la Carta Magna no sólo provocó un intenso debate durante el propio proceso electoral sino también durante los 100 primeros días de Gobierno de Humala. Si recordamos nuestros puntos de "Sección de publicación" o "Fuentes", El Comercio prioriza el tema de la economía y las voces de representantes del empresariado, quienes están públicamente en contra de un cambio constitucional porque consideran que además de afectar el orden jurídico, la Constitución de 1993 garantiza el actual modelo económico de libre mercado. Por otro lado, desde La República se ha señalado públicamente, a través de su línea editorial o columnistas, a la Constitución de 1993 como resultado de un régimen dictatorial y que sí se debería poner en discusión sobre ir reformándola de manera paulatina.

En cuanto a Igualdad ante la justicia, ambos diarios han dedicado una ubicación y extensión importante por la propia relevancia que tuvo la lucha frontal contra la corrupción para la opinión pública por esos días al ganar una opción electoral que se comprometía a luchar contra ella. Es importante recordar que dentro de esos 100 primeros días ocurrió el Caso Andauasi, en el que estuvo involucrado el ex Segundo Vicepresidente de la República, Omar Chehade Moya y que provocó finalmente su renuncia al cargo. Y como recalcamos, por esos días había una fuerte demanda de rendición de cuentas por parte de la ciudadanía incentivada en gran medida por uno de los más simbólicos compromisos de campaña de Humala a través de la frase "Honestidad para hacer la diferencia". 


\subsection{Resultados del análisis de contenido}

En esta etapa de nuestro estudio analizaremos el contenido de nuestro universo de noticias. Consideramos si cada política de inclusión social analizada fue o no una promesa de campaña de Ollanta Humala, determinamos si ambos medios demandan una mayor o menor participación del Estado en estas, identificamos cuáles fueron las políticas de inclusión social publicadas con mayor frecuencia (tanto por temas generales o macro como por casos específicos) y finalizaremos haciendo una valoración al obtener un promedio de "calificación" por parte de ambos medios a esos 100 primeros días de gestión.

\subsubsection{Promesas de campaña}

¿Cuántas de las noticias analizadas fueron promesas electorales?

Si bien las elecciones generales del año 2011 nos polarizaron también generaron un conjunto de expectativas en gran parte de la ciudadanía sustentadas en promesas de campaña que Ollanta Humala realizó durante dicho proceso. A continuación mostramos cuantas de las noticias de nuestro universo analizado fueron compromisos electorales:

Figura 4.2.1.1

Cantidad de noticias que fueron promesas de campaña (\%)

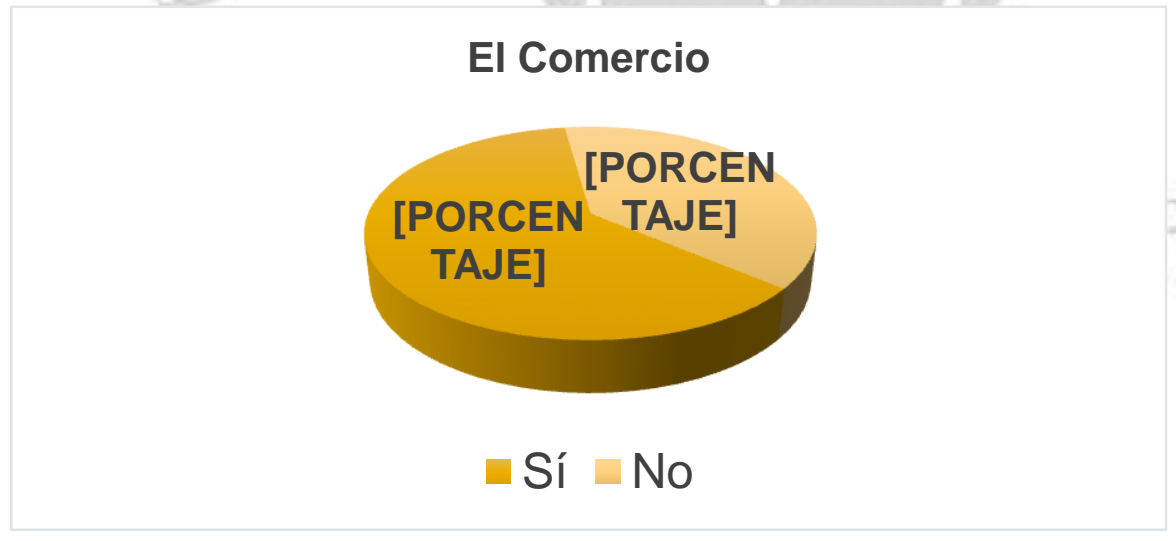

Fuente: Gráfica de elaboración propia

Figura 4.2.1.2 
Cantidad de noticias que fueron promesas de campaña $(\%)$

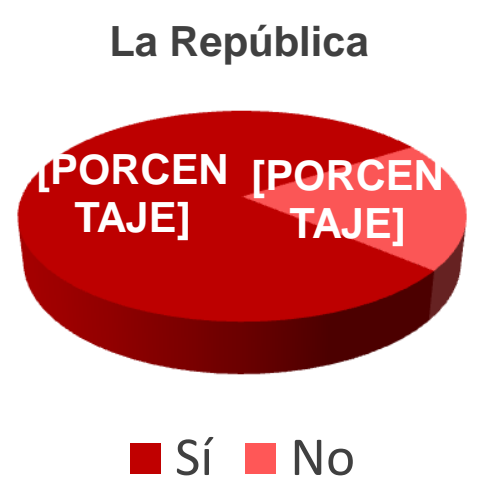

Fuente: Gráfica de elaboración propia

Los resultados nos indican que las políticas de inclusión social publicadas como noticias en ambos medios son promesas de campaña en su gran mayoría. En El Comercio un amplio 62\% Sí lo fueron y un menor 38\% No lo fueron, mientras que en La República, un contundente $80 \%$ Sí lo fueron y sólo un $20 \%$ No lo fueron.

Ante esto podemos señalar que la mayoría de noticias están relacionadas a promesas de campaña porque justamente la temática de la inclusión social fue un eje trasversal a lo largo de toda la propuesta electoral de Humala. Como hemos señalado antes, en ese contexto político la inclusión social se convirtió en un "significante flotante" (Laclau y Mouffe, 2005) que iba más allá de "incluir a los excluidos” sino además se vinculaba a la propia oferta electoral de Humala y propuestas como el impuesto a las sobreganancias mineras, Pensión 65, lucha contra la corrupción y un conjunto de planteamientos programáticos consagrados en el programa La gran transformación, La hoja de ruta y el Juramento por la democracia, pues si bien se realizaron ajustes al programa primigenio, el espíritu de este y sus principales propuestas continuaron en los otros dos documentos.

Por otro lado desde el enfoque de los medios, al haber debatido, criticado o apoyado las propuestas, tanto El Comercio como La República fueron una suerte de monitores sobre el cumplimiento, estancamiento u olvido de dichos compromisos electorales tan discutidos durante el proceso electoral. 


\subsubsection{Participación del Estado en políticas de inclusión social}

¿Cuál debería ser el rol de participación del Estado en las políticas de inclusión?

En esta parte del estudio analizamos cuál es el enfoque periodístico de ambos diarios sobre la participación que debería tener el Estado en cada variable, es decir, si el medio apuesta por una "Mayor participación del Estado" o "Menor participación del Estado".

Figura 4.2.2.1

Tendencia de la preferencia del diario sobre la participación del Estado por temáticas

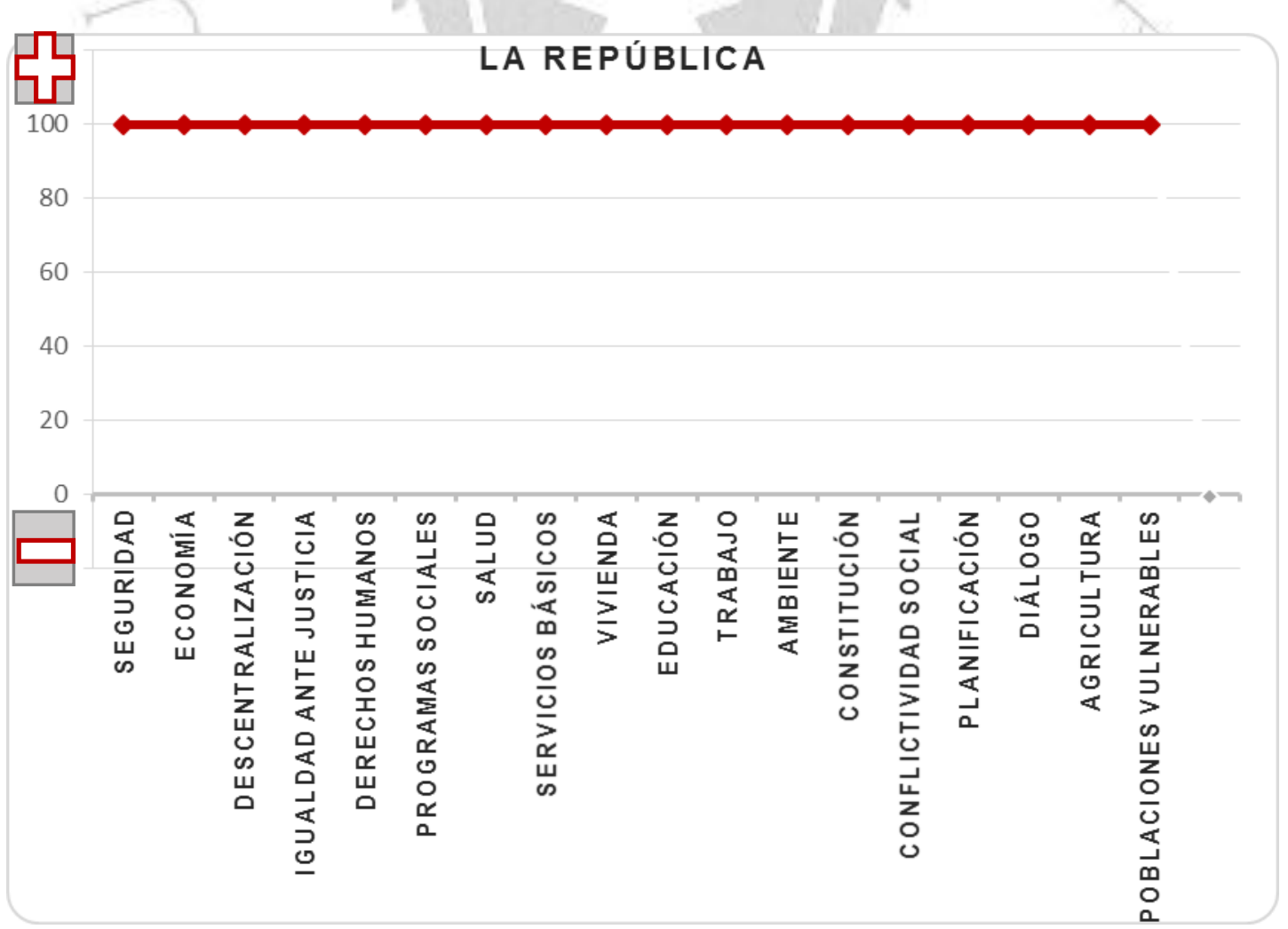


Fuente: Gráfica de elaboración propia

Figura 4.2.2.2

Tendencia de la preferencia del diario sobre la participación del Estado por temáticas

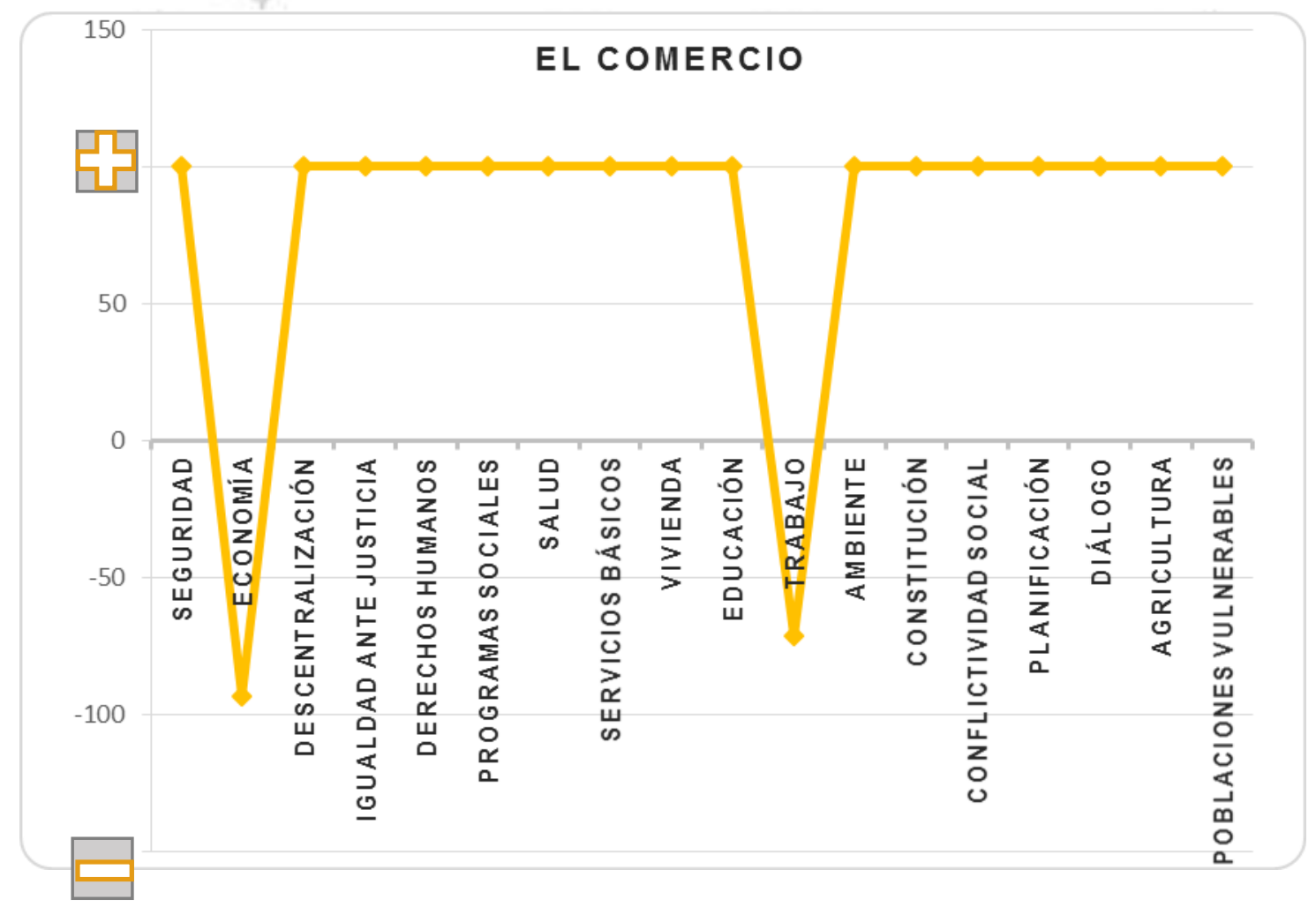

Fuente: Gráfica de elaboración propia

Mirando los resultados, queda claro que desde ambos medios hay una gran demanda de un Estado que participe activamente en el impulso de políticas de inclusión social en la 
mayoría de temas generales tomados en cuenta para este estudio, sin embargo, hay una importante diferencia en El Comercio y La República.

Mientras que La República demanda dicho estado activo en todas las variables analizadas (Seguridad, Economía, Descentralización, Igualdad ante la Justicia, Derechos Humanos, Programas Sociales, Salud, Servicios Básicos, Vivienda, Educación, Trabajo, Ambiente, Constitución, Conflictividad Social, Planificación, Diálogo, Agricultura y Poblaciones vulnerables), El Comercio demanda lo mismo con excepción de los temas centrales de Economía y Trabajo.

Ahora tomemos en cuenta una vez más el resultado de laFigura 4.1.2.1del análisis de forma de nuestro estudio (Sección de publicación) en el que identificamos que El Comercio tiene una mayor frecuencia de publicación de noticias sobre inclusión en la sección Economía (45\%) y en segundo término en la sección Política (36\%). Nuestra conclusión fue que para este medio el grueso de las políticas de inclusión social se concentran en mantener una estabilidad y crecimiento económico sostenido. Entonces podemos señalar que El Comercio sí quiere un Estado más participativo en la mayoría de sectores de interés nacional, pero que ese Estado no amplíe su participación en el sector economía ni en el de trabajo, ambos estamentos centrales del modelo económico actual de libre mercado del que tanto este diario como los gremios empresariales como Confiep o SNI hacen una férrea defensa pública.

Porque lo consideramos relevante, profundizaremos más sobre este resultado de El Comercio en el siguiente punto. Desglosaremos las políticas de inclusión social específicas que conforman tanto la variable economía como la de trabajo.

\subsubsection{Participación del Estado en casos "Economía" y "Trabajo" en EI Comercio}

¿Cuál debería ser el rol de participación del Estado en la economía y trabajo?

A continuación presentamos los resultados sobre la participación que debería tener el Estado acerca de las variables economía y trabajo desde la línea editorial de El Comercio: 
Figura 4.2.3.1

Tendencia de la preferencia del diario sobre la participación del Estado en economí

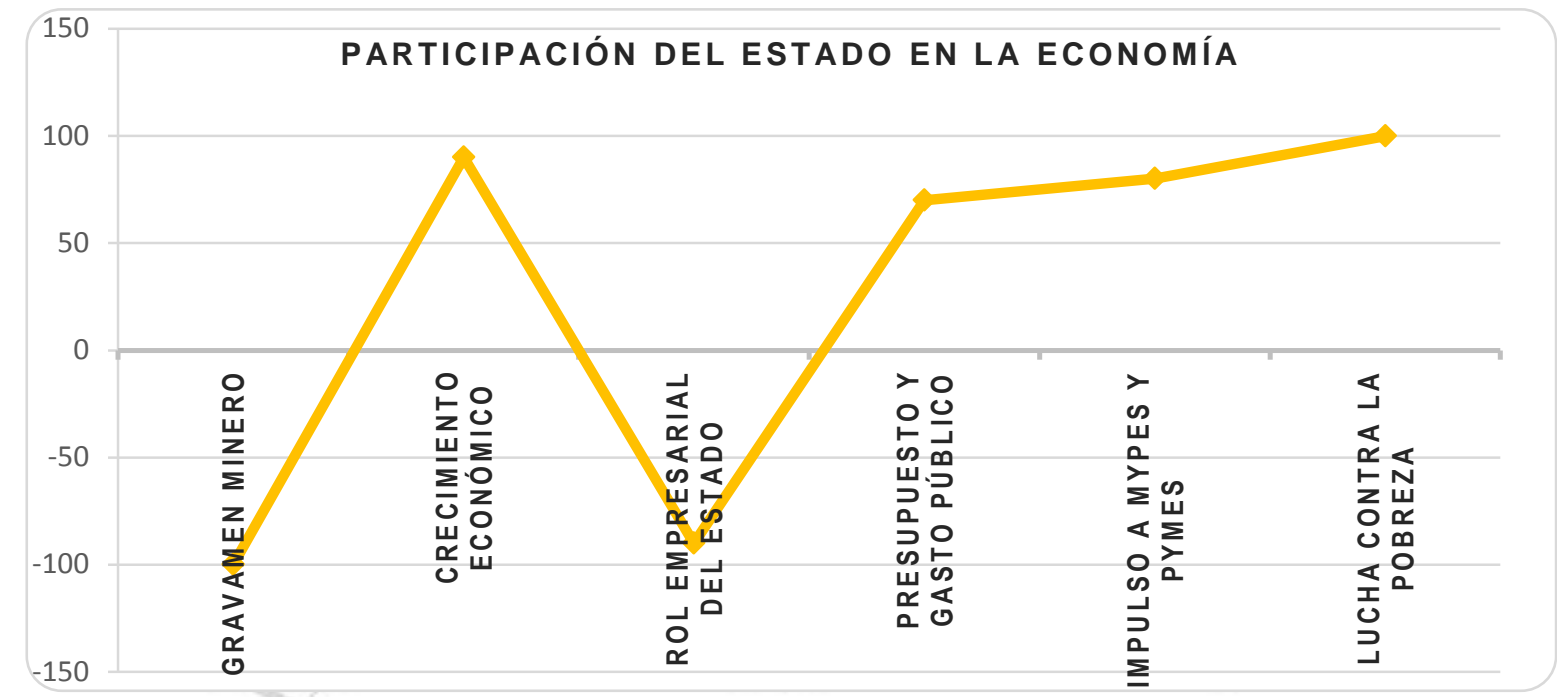

Fuente: Gráfica de elaboración propia

Figura 4.2.3.2

Tendencia de la preferencia del diario sobre la participación del Estado en trabajo

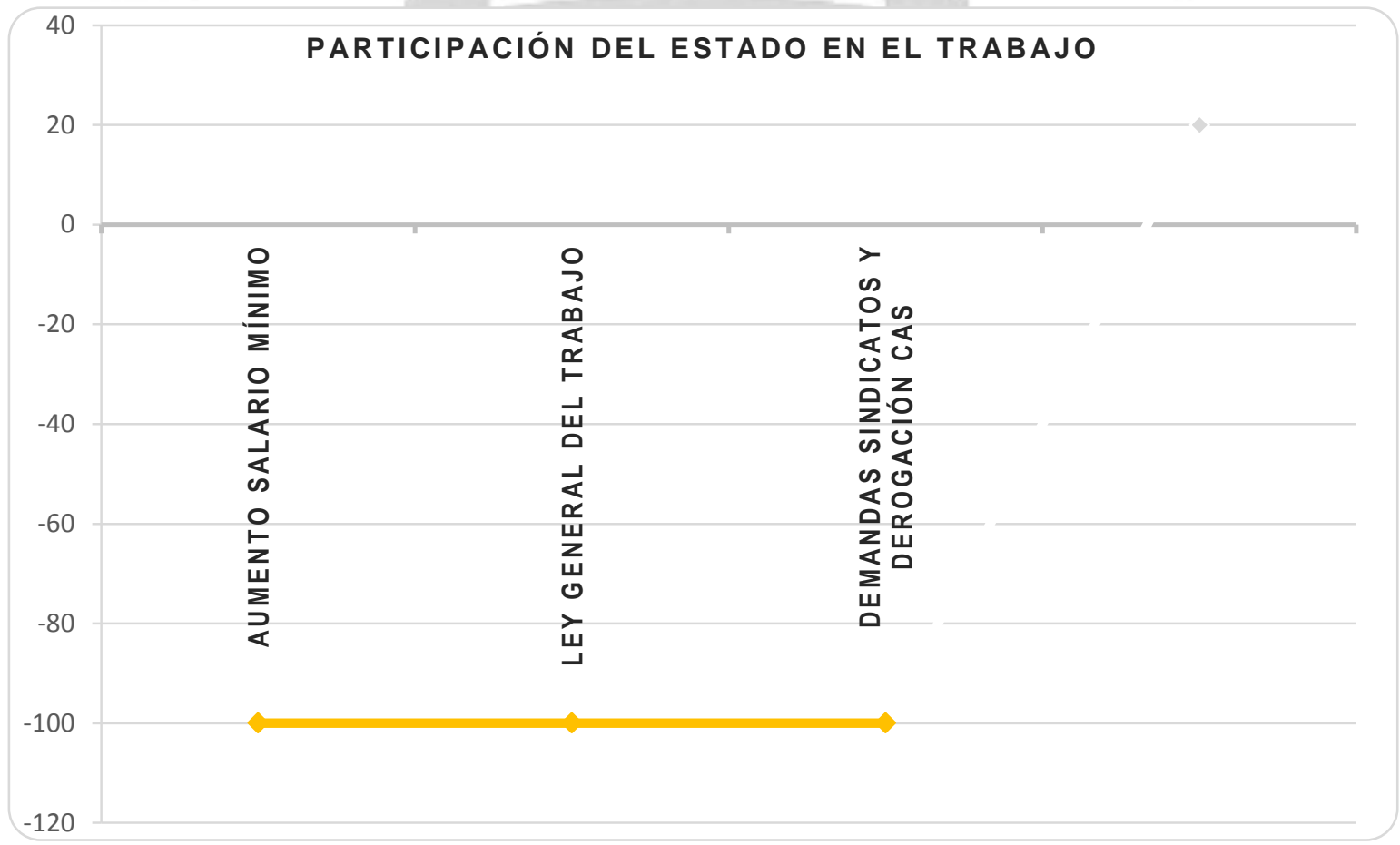

Fuente: Gráfica de elaboración propia

En cuanto a Economía, observamos en los resultados un enfático rechazo por parte de

El Comercio a que el Estado tenga una participación activa en el tema de Gravamen 
minero (cuyo debate no sólo se dio durante la campaña electoral sino que continuó durante los 100 primeros días de Gobierno) y Rol empresarial del Estado (que desde la campaña este medio rechazó pública y enfáticamente).

En contraste, El Comercio sí considera que el Estado debe tener una mayor participación en el impulso de políticas de inclusión social para el Crecimiento económico, en una mejor ejecución del Presupuesto y gasto público, en el Impulso a Mypes y Pymes y, finalmente, para la Lucha contra la Pobreza.

A partir de esto podemos concluir que El Comercio no se opone al tema económico en su conjunto, es más, en lo vinculado directamente a la temática tradicional de inclusión social como "Lucha contra la pobreza" demanda un liderazgo estatal. Sin embargo, en lo que tiene que ver con una economía empresarial sí plantea un claro rechazo a que ese Estado la regule, burocratice o interfiera a nivel de reformas tributarias (impuestos como el "gravamen minero" al sector que hasta hoy lidera nuestras exportaciones nacionales) o reformas laborales (cambios en políticas de trabajo actuales por demanda de sectores sindicales como el aumento del sueldo mínimo vital). En ambos casos, temas que involucran al empresariado y grupos de poder nacional.

Por otro lado, el rechazo del Rol empresarial del Estado bajo la premisa que el Estado no es un buen administrador está muy vinculado a la defensa del actual modelo económico de libre mercado que, como hemos visto en puntos anteriores, este diario secunda públicamente.

\subsubsection{Políticas macroo generales de inclusión social priorizadas}

¿Cuáles son las políticas generales que más se publicaron en ambos medios?

En esta parte de nuestro estudio, analizamos los resultados de las políticas de inclusión social por variables macro o generales que se priorizaron en El Comercio y La República durante los primeros 100 días del gobierno de Humala:

Figura 4.2.4.1 
Frecuencia de preferencia en publicación por temas generales (\%)

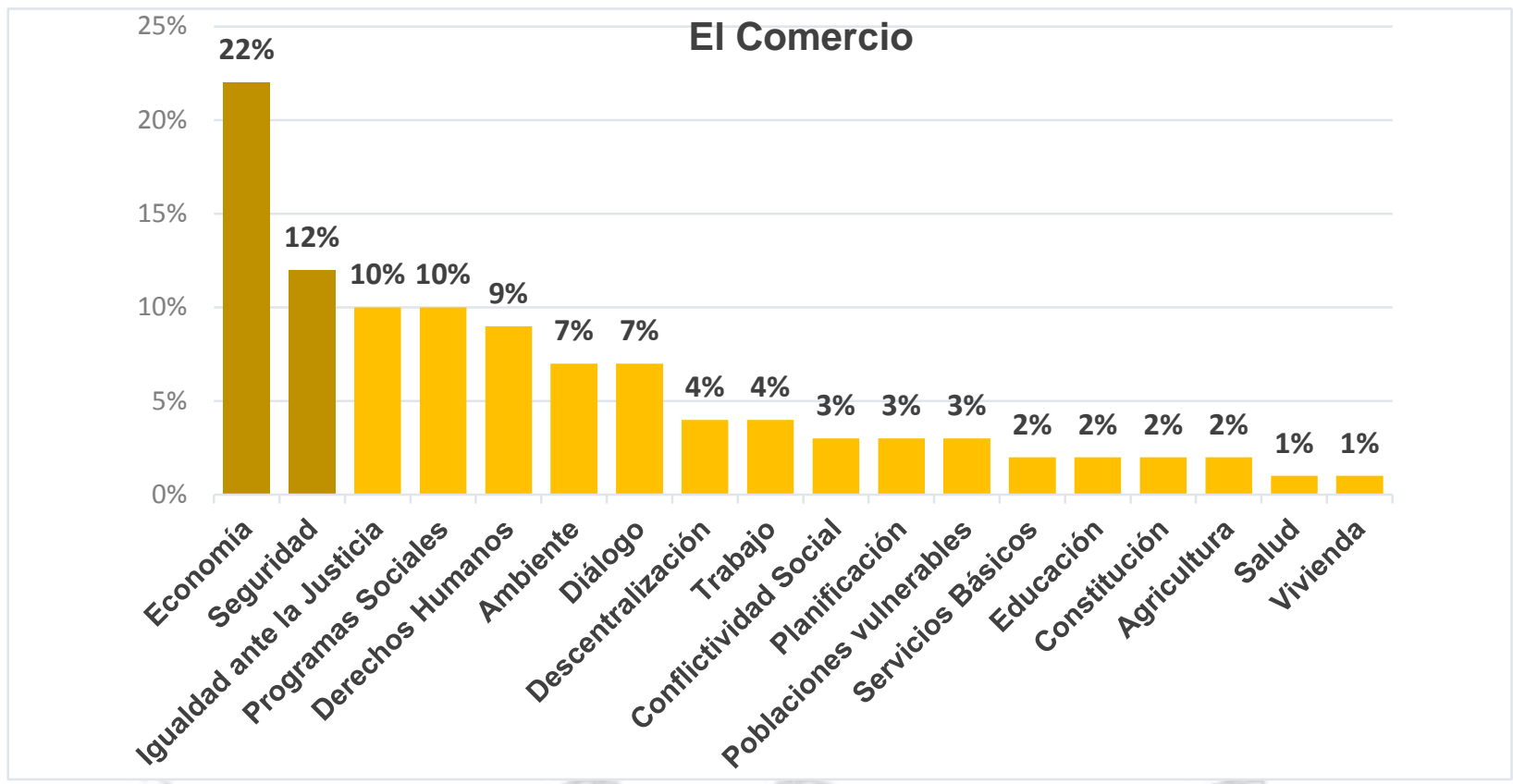

Fuente: Gráfica de elaboración propia

Figura 4.2.4.2

Frecuencia de preferencia en publicación por temas generales (\%)

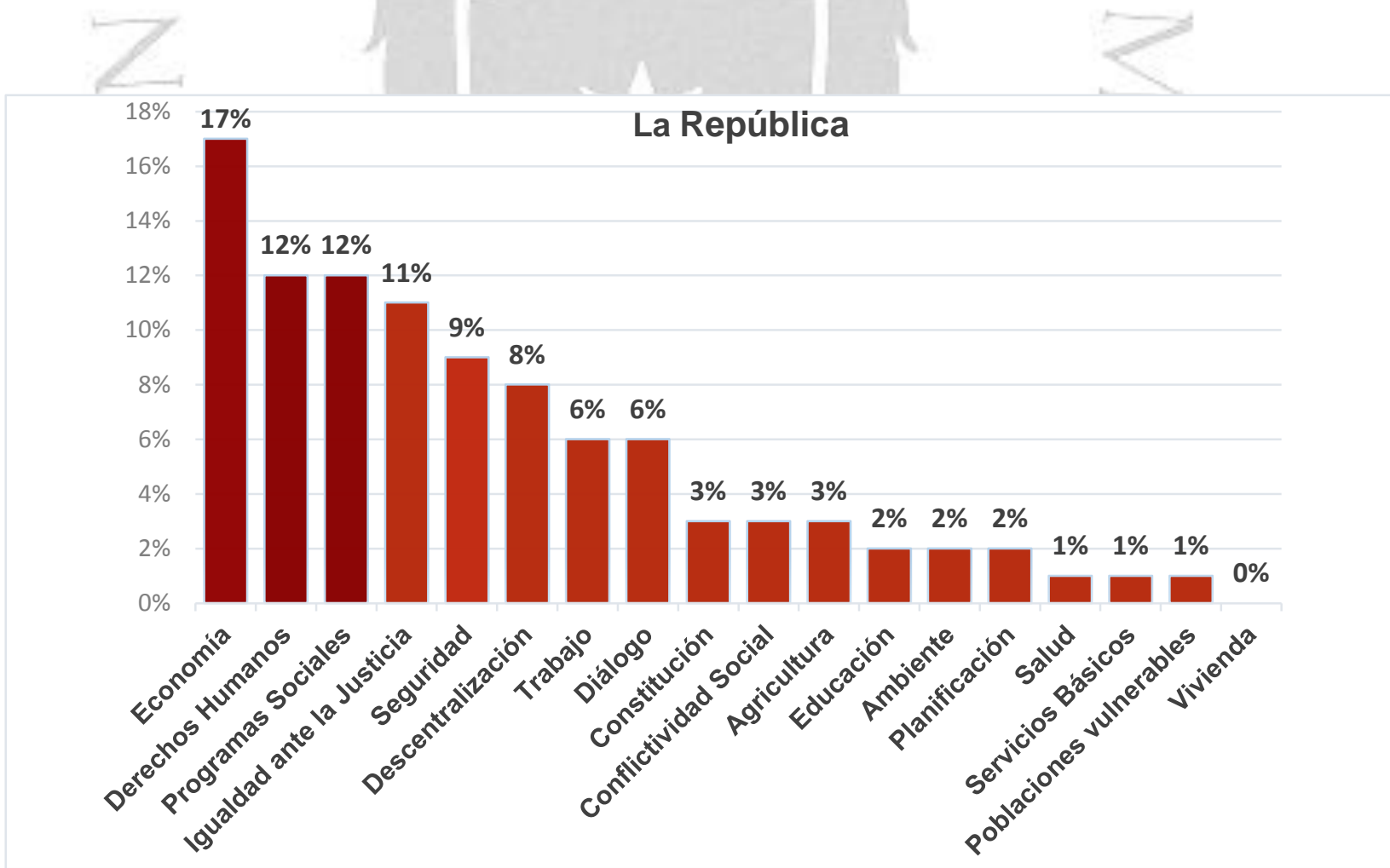

Fuente: Gráfica de elaboración propia 
A partir de los resultados podemos concluir que el elemento Economía(El Comercio $22 \%$ y La República 17\%) es no sólo el de mayor frecuencia de publicación sino tal vez el de mayor relevancia para ambos diarios (al considerar también los resultados de gran parte de los puntos anteriores de nuestro estudio).

Por otro lado, una vez más obtenemos coincidencias en ambos diarios. La variable de Igualdad ante la Justicia(El Comercio 10\% y La República 11\%) está -como hemos mencionado antes- relacionada a la promesa electoral de lucha contra la corrupción que impulsó el propio ex presidente Humala durante su campaña bajo el lema "Honestidad para hacer la diferencia” y Programas sociales(El Comercio 10\% y La República 12\%) que fue uno de los temas centrales en la propuesta programática de Gana Perú.

En cuanto a las diferencias, tenemos que en El Comercio tiene a Seguridad (12\%) con una alta frecuencia de publicación que la hace ubicar el segundo lugar y en La República tenemos a Derechos Humanos (12\%) en el mismo puesto. Este último resultado se vincula mucho a la identidad de cada medio, El Comercio respondiendo a la constante demanda ciudadana de una mayor seguridad que además no genere inestabilidad social ni económica y para la República, el tema de derechos humanos, al que históricamente su línea editorial y muchos de sus columnistas están vinculados.

Ahora volvemos a traer a colación el tema Economía, puesse vincula a las otras temáticas que se ubicaron en los segundos y terceros lugares en ambos diarios. Esto ocurre ya que, por ejemplo, cuando se habla de Programas sociales se discute también cómo se financiarán los mismos o cuando se habla de Seguridad, se tiene en cuenta cómo se debería priorizar los recursos para la policía nacional o si es viable con el presupuesto estatal aumentar o no sus salarios. Por esto, podemos afirmar que el tema Economía(El Comercio 22\% y La República 17\%) no sólo es claramente el de mayor frecuencia de publicación en ambos diarios, sino además que las otras temáticas que también presentan una alta frecuencia de publicación suelen tener componentes vinculados del tema económico. 
Cabe resaltar poca prioridad periodística que ambos diarios le otorgan a las políticas de inclusión social más tradicionales. Observamos que temáticas como Salud, Vivienda, Servicios básicos y hasta Educación ocupan los últimos lugares a lo largo de este estudio. Este resultado es curioso y puede resultar preocupante por lo trascendental que son estos sectores para alcanzar la tan comentada inclusión social y por lo poco que se pone en agenda en los dos principales medios de prensa de nuestro país.

\subsubsection{Políticas de inclusión social por casos priorizados}

¿Cuáles son los casos específicos que más se publicaron?

Desglosando el punto anterior, en esta parte del estudio seleccionamos el caso con mayor frecuencia de publicación dentro de cada una de las variables de políticas de inclusión social macro analizadas:

Figura 4.2.5.1 
Frecuencia de preferencia en publicación por casos específicos (\%)

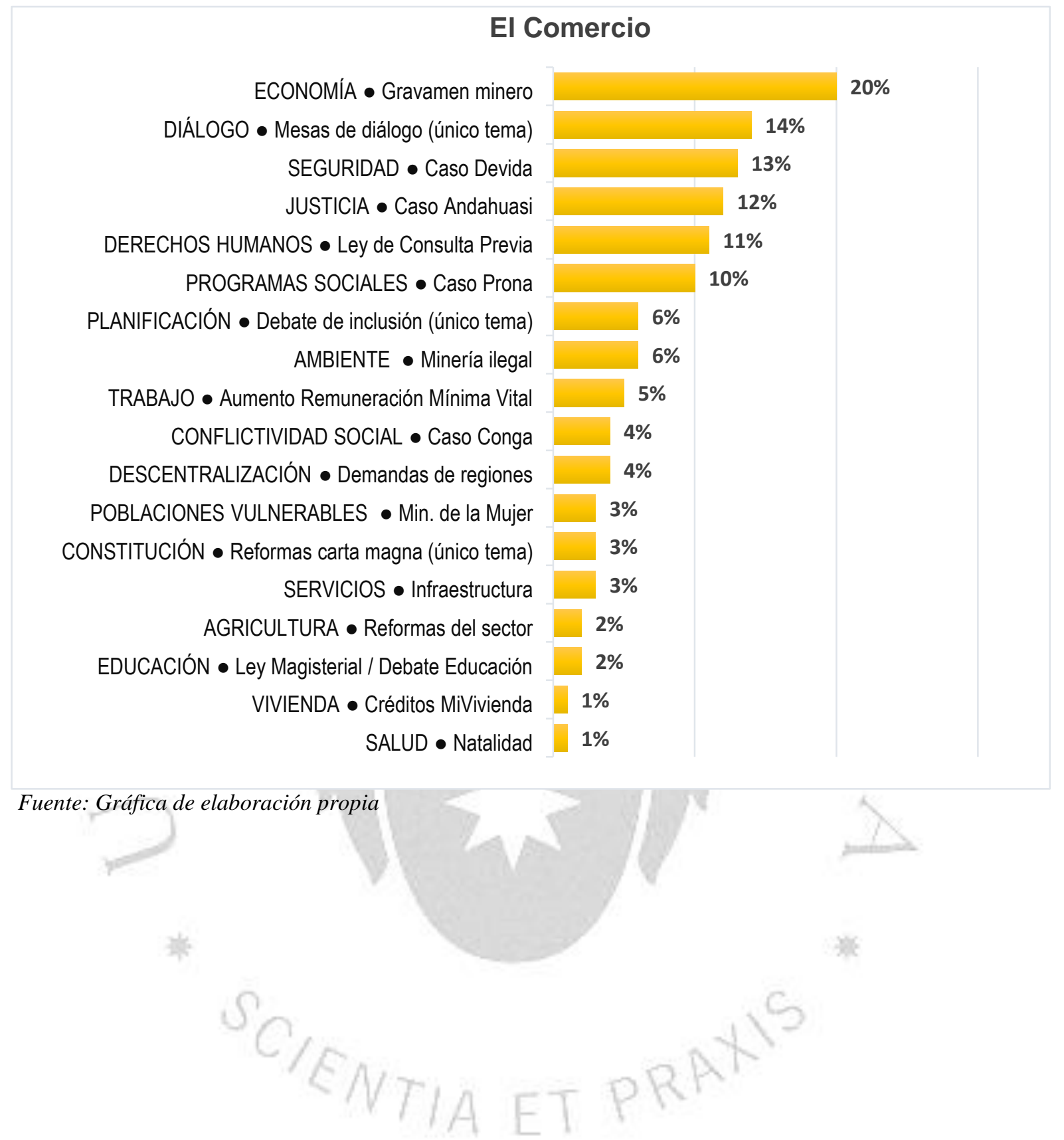

Figura 4.2.5.1 
Frecuencia de preferencia en publicación por casos específicos (\%)

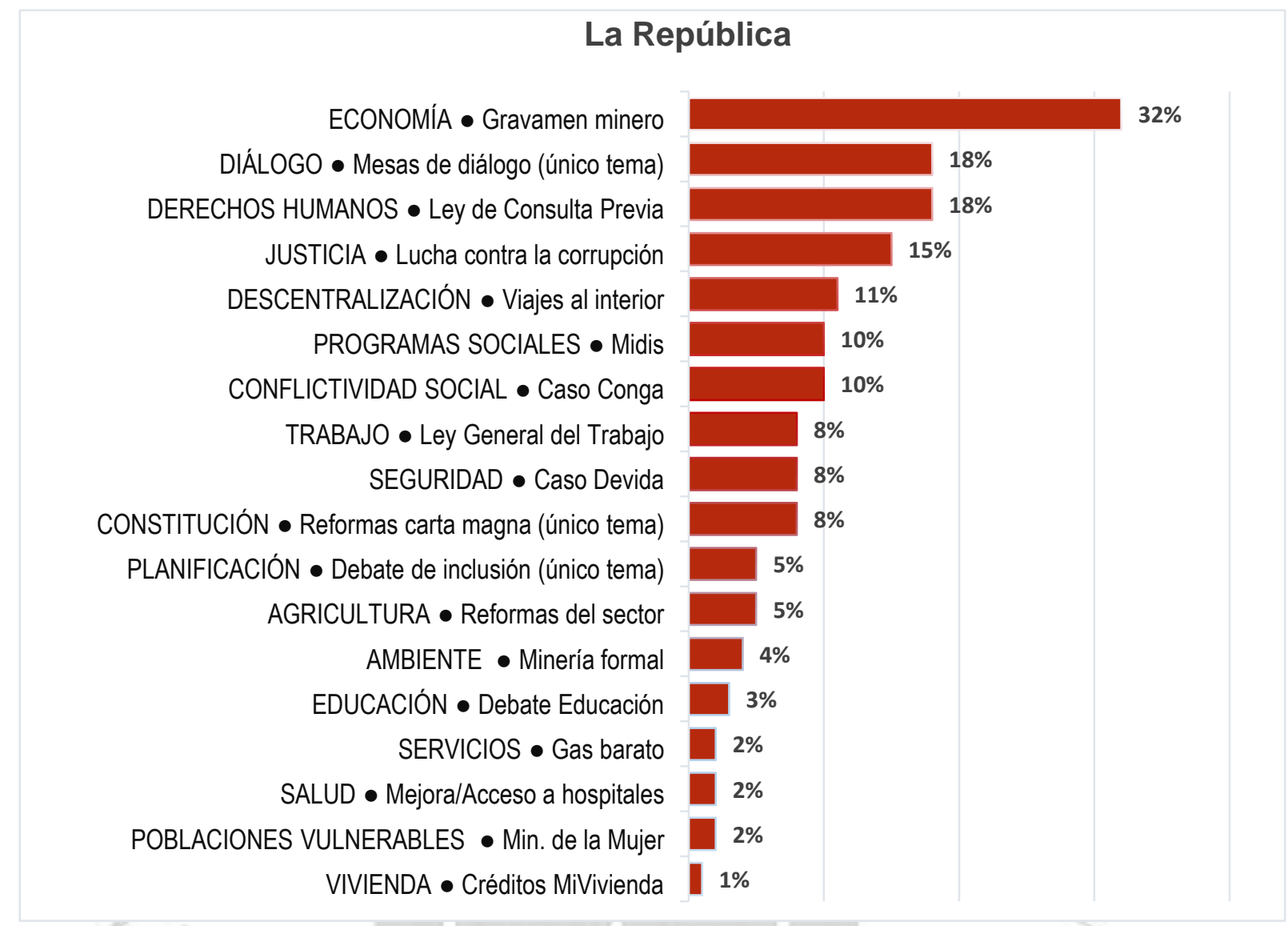

Fuente: Gráfica de elaboración propia

Como lo ha mostrado la tendencia a lo largo de este estudio, Economía continúa liderando los resultados. Esta vez hemos desglosado las políticas generales (en este caso específico a Economía) para saber cuál de sus variables de análisis son las de mayor frecuencia de publicación, por ejemplo, en Economía el tema de Gravamen minero (El Comercio $20 \%$ y La República 32\%) lidera la lista en ambos diarios. La discusión sobre el llamado en campaña "Impuesto a las sobreganancias mineras" no sólo generó un intenso debate durante las Elecciones generales del 2011 sino también durante los 100 primeros días del Gobierno de Humala, ya que durante ese periodo se definiría su viabilidad y su futura reglamentación y temporalidad de ejecución. Por ello, ese fue el tema del que más se publicó tanto en El Comercio (con una posición más crítica) como en La República (que secundó la propuesta) provocando así una disputa de intereses tanto políticos como económicos. 
La segunda temática específica de la que más se publicó fue acerca del Diálogo y las Mesas de diálogo(El Comercio 14\% y La República 18\%). Por dicha temática entendemos sobre aquellas noticias que informaron de espacios de negociación y recojo de demandas de las regiones (autoridades regionales y organizaciones sociales o de la sociedad civil) hasta encuentros y conversaciones con gremios empresariales o sindicales. Consideramos que el tema diálogo ocupa el segundo lugar con una alta frecuencia de publicación por tanto las propias expectativas de "escuchar a la población" que se generaron en la campaña de Ollanta Humala como también por conflictos social en el gobierno que lo antecedió, recordando el Caso del "Baguazo" durante el periodo del ex presidente Alan García en el 2009.

Siguiendo con la lógica tanto de expectativas como de prevención de conflictos mediante el diálogo, tenemos también con una alta frecuencia de publicación a la política sobre Derechos Humanos, puntualmente la Ley de Consulta Previa(El Comercio $11 \%$ y La República $18 \%$ ). Este caso resulta particular, ya que el tratamiento periodístico desde ambos medios de prensa fue sumamente propositivo, no sólo apoyando la promulgación de la ley que responde al Convenio 169 de la OIT, sino además expresando públicamente cierto apoyo mediático a través de las opiniones de especialistas y líneas editoriales que se mostraron a favor de su promulgación en cada noticia en la que el tema fue tratado.

Ahora tomemos tres temas macro o generales que han estado muy presentes a lo largo de este estudio desde su frecuencia de publicación en ambos diarios: Seguridad, Igualdad ante la Justicia y Programas Sociales.

Comenzando con el tema general de seguridad. Observamos que la temática específica de mayor frecuencia de publicación fue el Caso Devida(El Comercio 11\% y La República 18\%) en el que se ponía en cuestión la designación de Ricardo Soberón como jefe de dicha institución por sus supuestos vínculos con los cocaleros (quienes estaban en contra de la política de erradicación). Esto ocurrió durante el mes de Agosto (2011) y fue el primer cuestionamiento político y mediático que tuvo que enfrentar el Gobierno 
de Humala. Y si bien El Comercio fue bastante más crítico que La República, ambos le dieron una importante relevancia en términos de la frecuencia de publicación.

En contraste, cuando revisamos los resultados sobre los temas generales de Igualdad ante la Justicia y Programas Sociales sí notamos una clara diferencia de prioridades de publicación entre ambos medios. Mientras que para La República el tema del que más se publicó sobre Igualdad ante la Justicia fue Lucha contra la corrupción (15\%) (medidas para combatir la corrupción en los tres niveles de gobierno en general), para El Comercio la variable más publicada sobre el mismo tema fue Caso Andahuasi (12\%) que ya en laFigura 4.1.4.1sobre "Página y ubicación" ahondamos en el daño político que le produjo al Gobierno al nivel de provocar la renuncia de su segundo vicepresidente, Omar Chehade Moya. Un patrón similar se da en el tema general de Programas sociales, mientras que en La República el tema específico del que más se publicó fue sobre el MIDIS (10\%), es decir, acerca de la creación del entonces nuevo Ministerio de Desarrollo e Inclusión Social, para El Comercio el tema con mayor frecuencia de publicación fue el Caso Pronaa (10\%), tema que puso en cuestión a la entonces Ministra de la Mujer y Poblaciones vulnerables, Aída García-Naranjo, por su responsabilidad ante la muerte por intoxicación de tres niños en el Caserío de Redondos (Cajamarca).

Acerca de este patrón en el tratamiento que tuvo El Comercio sobre estos tres temas (Seguridad, Igualdad ante la Justicia y Programas sociales) señalamos que los casos de mayor frecuencia de publicación tienen como protagonistas a personajes de alto nivel político y de confianza/del Gobierno (el jefe de Devida, un Vicepresidente y una Ministra de Estado). Así los Casos Devida, Andahuasi y Pronaa, más allá de mostrar la debilidad institucional y del propio Ejecutivo, resultaron tres elementos para arrinconar o cuestionar políticamente al entonces nuevo Gobierno de Humala. Coincidentemente además los tres personajes en cuestión pertenecen al sector de izquierda que acompañó a Humala tanto en el proceso electoral como en el inicio de gestión. 
McCombs plantea esta influencia como el Establecimiento de la agenda o "agendasetting", pues los medios tienen impacto en la opinión pública al determinar qué temas tienen interés informativo o no y el espacio que le asignan a estos (McCombs, 1972).

En ese sentido, el internacionalista Farid Kahhatt señala que en el marco de elecciones los medios en nuestro país responden especialmente a la voluntad de sus propietarios. Da como ejemplo que el respaldo del New York Times y Wall Street Journal a Barack Obama y John McCain respectivamente se dio a través de sus páginas editoriales y no con su cobertura informativa como ocurre en Perú (América Económica, 2011).

\subsubsection{Valoración}

¿Qué calificación le da en promedio cada medio a las políticas de inclusión?

En esta última etapa de nuestro estudio presentamos el promedio de las valoraciones que se dieron desde El Comercio y La República a cada una de las 468 noticias analizadas con respecto a la performance del gobierno durante esos 100 primeros días de gestión, es decir, si se considera que se avanzó en la política de inclusión social o no.

Para medir dicha valoración les dimosa cada noticia un puntaje del 1 al 5, luego promediamos todo el universo de estudio de cada uno de los diarios por separado y finalmente homologamos el resultado con una calificación sobre 20 puntos.

Figura 4.2.6.1

Valoración de cada medio a la performance en las políticas de inclusión social en el Gobierno de Humala (\%)

\section{El Comercio}

- La República
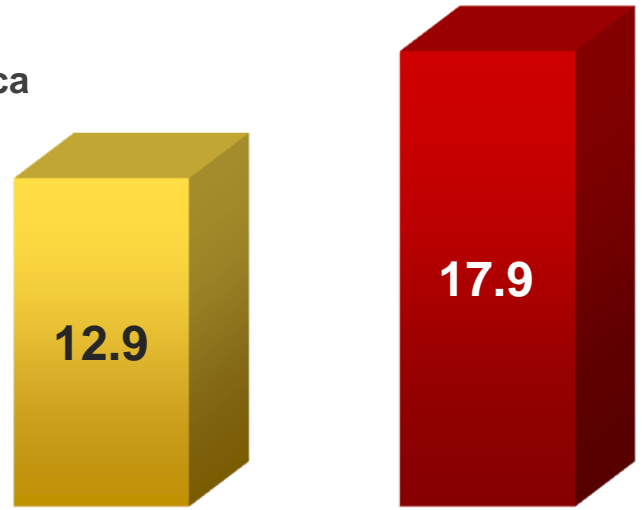
Los resultados señalan de las valoraciones son las siguientes: El Comercio $2.58 \mathrm{pt}$ (12.9) y La República 3.58 pt $(17,9)$. Ambos medios de prensa le otorgan una calificación aprobatoria a la performance del Gobierno de Humala en relación a su gestión en las políticas de inclusión social que estuvieron en agenda en esos 100 primeros días; sin embargo, hay una considerable diferencia de cinco puntos entre sus resultados los cuales relacionamos con dos elementos: temor y expectativas.

Por un lado, La República, que secundó -especialmente en la segunda vuelta- la propuesta de Gana Perú, recogió un conjunto de expectativas en materia social con las que el Gobierno de Humala tuvo importantes acciones y gestos políticos para su cumplimiento. Además no se alteró ningún orden constitucional y hubo un compromiso claro por cumplir promesas vinculadas a derechos humanos, lo que le valió una calificación de 17,9.

Por otro lado, El Comercio, que tuvo muchos reparos sobre el propio Humala, quienes lo acompañaban y sus propuestas durante todo el proceso electoral, despejó muchos de sus temores durante esos 100 primeros días. Esto especialmente se dio con el nombramiento de Miguel Castilla como Ministro de Economía (ex Viceministro del gobierno predecesor de Alan García) y la permanencia Julio Velarde en el Banco Central de Reserva - BCR que fueron una suerte un guiño muy bien recibido para el sector empresarial, además de no tocar los fondos de las AFP para los programas sociales o el abandono momentáneo de la propuesta de cambio constitucional. En síntesis, unos 100 primeros días sin lo que El Comercio consideraría "excesos", así ese 12,9 resulta una nota relativamente alta en comparación a la que le hubiera puesto durante la propia campaña, probablemente una bastante menor y desaprobatoria. 


\section{CONCLUSIONES}

A lo largo de esta investigación hemos logrado identificar las prioridades, coincidencias, diferencias de los dos más importantes diarios del país, El Comercio y La República, sobre el tratamiento informativo de las políticas de inclusión social impulsadas durante los 100 primeros días del Gobierno de Ollanta Humala. A continuación nuestras reflexiones finales:

\section{El factor económico en la inclusión social}

Para ambos diarios el principal enfoque temático ha sido la economía (en El Comercio $22 \%$ y en La República 17\%), porque la entienden como central cuando se habla de inclusión social y es un patrón constante en los resultados a lo largo de nuestro estudio. Sin embargo, para El Comercio la inclusión tiene un mayor vínculo con el factor económico (32\% por encima de La República) y, después de los representantes del Gobierno, les ha conferido más voz como fuentes a los empresarios $(9 \%$ por encima de La República), principalmente de grandes corporaciones trasnacionales del sector minero que hasta hoy tiene una gran importancia en la recaudación económica del país. Es allí donde se vincula el caso del que más se publicó en ambos diarios: el gravamen minero o impuesto a las sobreganancias mineras al que La República le dio más énfasis a través de una mayor cobertura (12\% por encima de El Comercio).

Podemos señalar entonces que si bien ambos diarios le dieron importancia a la temática económica, El Comercio además visibilizó más la voz de los grandes empresarios del sector minero y sus intereses y, en ese sentido, no es coincidencia que el caso del que más se publicó en ambos diarios durante los 100 días de Humala sea justamente sobre el gravamen minero.

\section{Sobre la participación del Estado}

Para ambos diarios cuando se informa sobre la inclusión social es importante hacer un vínculo con el Gobierno, cuyos representantes como ministros o presidente son visibilizados en la mayoría de fotos que acompañan dichas noticias (primer lugar en 
ambos diarios con casi el 50\%). Además se considera al Gobierno como principal fuente válida cuando se habla del tema(El Comercio con $38 \%$ y, con mayor énfasis, en La República con 58\%), es decir, ambos medios sugieren que el Gobierno es en la práctica el principal responsable de que se consolide o retrase el proceso de inclusión social en nuestro país. Asimismo, ambos consideran vital en dicho proceso de inclusión social la participación del Estado a través del Gobierno en políticas sociales y económicas, pero mientras que La República es importante tener al Estado como un actor regulador en la economía, para El Comercio debería serlo sólo en lo que se refiere al crecimiento económico y lucha contra la pobreza, mas no impulsando reformas tributarias como el gravamen minero o reformas laborales como el aumento del sueldo mínimo vital, elementos que principalmente afectan al empresariado (a quienes El Comercio le suele otorgar una mayor voz).

\section{El modelo económico}

Tanto la primacía constante del factor económico a lo largo de este estudio como la de la propia participación del Estado en sectores como economía y trabajo tienen su principal sustento en el actual modelo económico de libre mercado. Es decir, los principales postulados de este modelo nos plantean no sólo una economía abierta al mundo a través de un conjunto de tratados comerciales sino también una menor participación del Estado principalmente en la economía (pues el trabajo también está vinculado a este sector) y tiene como principal forma de materialización en nuestro país a la Constitución del 1993 y es así que fue el tema de mayor extensión de publicación en ambos diarios con alrededor de un $10 \%$, pues el debate de modificarla o no demanda una extensa explicación de argumentos jurídicos y políticos y es así que las políticas de inclusión social, la economía y la participación del Estado terminan por vincularse al actual modelo y a la actual Carta Magna.

Para terminar, podemos señalar que la inclusión social es un elemento que en determinado contexto político puede contemplar un conjunto de significantes que van más allá de los tradicionales programas sociales y que podría contemplar toda una oferta electoral. Es así que casi el total de las políticas de inclusión social analizadas durante este estudio fueron promesas de campaña (El Comercio 62\% y La República 80\%). Estas generaron expectativas en la ciudadanía que eligió a Ollanta Humala para ser 
presidente como también en los dos más importantes diarios del país, El Comercio y La República, que fueron una suerte de monitores del accionar del Gobierno durante sus primeros 100 días y tuvieron como eje central todo aquello que pudiera afectar la economía, así concluimos que -ya sea por diversos intereses- esta es una pieza clave cuando ambos medios informan sobre la temática dela inclusión social.

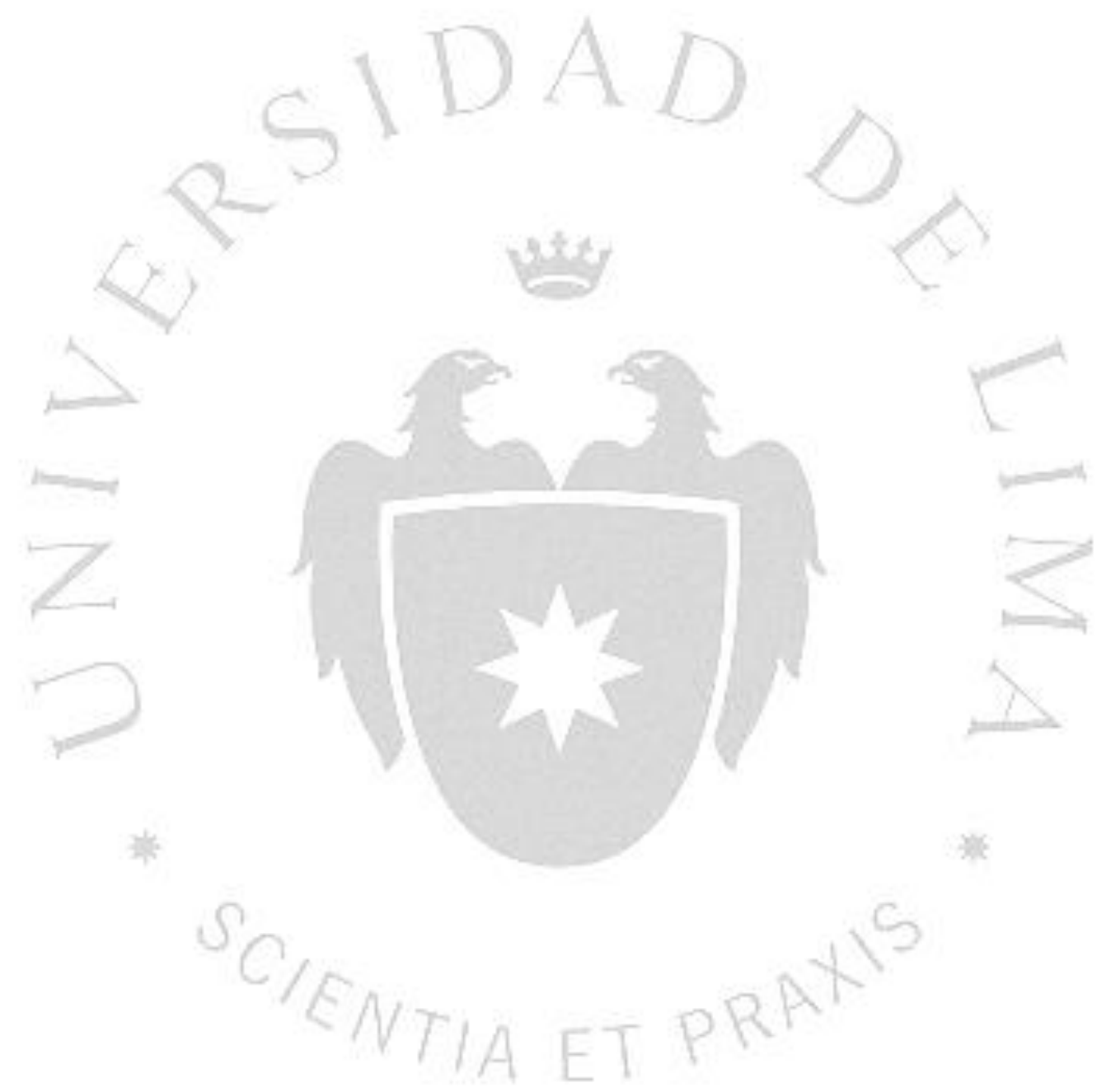




\section{RECOMENDACIONES}

Luego del proceso de estudio nos quedan también aprendizajes y recomendaciones que queremos compartir con otros investigadores:

- Es central determinar una línea metodológica de investigación cuando trabajamos un concepto que puede resultar gaseoso como "inclusión social". Para ello, es importante plantear y justificar teóricamentenuestras variables. En este caso, consideramos al concepto de inclusión social en el marco político electoral del 2011 como "significante flotante".

- A poco de iniciado el Gobierno con Pedro Pablo Kuczynski, sería una buena idea que, utilizando esta metodología propuesta, otros investigadores puedan emprender un análisis del tratamiento mediático de sus primeros 100 días, o tal vez a los últimos 100 días de Humala o de alguna otra gestión.

- Si bien hay supuestos muy recurrentes como que El Comercio le da más voz a los empresarios o que La República respalda una mayor participación del Estado, estudios como este se pueden convertir en una herramienta de sustentación y argumentación metódica y científica. He allí la importancia de concretar investigaciones como esta.

- A los estudiantes de la Facultad de Comunicación que desean realizar investigaciones con un enfoque de análisis político y no identifican aún una manera estratégica de hacerlo, animarlos a que utilicen las propias herramientas que nos brinda la comunicación como el análisis de contenido y los métodos cualitativos y cuantitativos para lograrlo. 


\section{BIBLIOGRAFÍA}

1) Alsina, Miguel Rodrigo (1993).La construcción de la noticia. Barcelona. Paidós.

2) Baldessar, M. J. (2005).Ni McLuhan ni McBride, ¿y ahora? Question.

3) Béjar, Héctor y César Lévano, César Hildebrandt (2008).Poder mediático. Lima: Fondo Editorial Universidad Ciencias y Humanidades.

4) Canell, María José (2006).La comunicación política. Una guía para su estudio y práctica. Madrid: Tecnos.

5) Dittus, Rubén (2006).La opinión pública y los imaginarios sociales: hacia una redefinición de la espiral del silencio. España: Red Athenea Digital.

6) Gonzales de Olarte, Efraín y Javier Iguiñiz (2009).Desarrollo económico y bienestar. Lima: Pontificia Universidad Católica del Perú, Fondo Editorial.

7) Laclau, Ernesto y Chantal Mouffe (1987).Hegemonía y estrategia socialista: Hacia una radicalización de la democracia. Madrid: Siglo XXI.

8) Laclau, Ernesto (2005).La razón populista. México, Argentina, Brasil, Chile, Perú, España, Estado Unidos, Colombia, Guatemala, Venezuela: Fondo de cultura económica.

9) López, Sinesio (1997).Ciudadanos reales o imaginarios: concepciones, desarrollo y mapas de la ciudadanía en el Perú. Lima: IDS.

10) Marx, Karl (1971). El Capital I. Buenos Aires: Signos.

11) McCombs, Maxwell (1992).Explorers and surveyors: Expanding strategies for agenda setting research. Journalism Quarterly.

12) Meiklejohn, Alexander (1961). "The First Amendment is an Absolute”.Nueva York: Supreme Court Review.

13) Sánchez-Parga, José (2005).Poder y política en Maquiavelo. Rosario: Homo Sapiens Ediciones.

14) Sen, Amartya y Bernardo Kliksberg (2009).Primero la gente. Buenos Aires: Temas Grupo Editorial.

15) Silver, Hilary (2003).Social Exclusion. The European Approach to Social Disadvantage.Denver: Indicators. 


\section{Otras consultas:}

- Agencia de Noticias Andina (2011).Presidente Humala: "La inclusión social se inicia reconstruyendo Pisco y la dignidad de su pueblo". Andina. $<\underline{\text { http://www.andina.com.pe/Espanol/Noticia.aspx?id=BK1F7vhE3B }}$ $\underline{8}=>$ [Consulta: 30 de Setiembre del 2015.]

- Maldonado, Rocío (2001). “Ollanta Humala no podrá eludir demandas sociales".La República, 07 de Junio. <http://www.larepublica.pe/07-062011/ollanta-humala-no-podra-eludir-demandas-sociales>. [Consulta: 18 de Setiembre del 2015.]

- Presidencia de la República del Perú (2011). "Discurso 28 de Julio del presidente Ollanta Humala". <http://www.presidencia.gob.pe/discurso-delpresidente-ollanta-humala-28-de-julio-2011>. [Consulta: 12 Setiembre 2011]

- Kahhat, Farid (2011). Medios y poder en el Perú de hoy. América Económica $<$ http://www.americaeconomia.com/politicasociedad/politica/medios-y-poder-en-el-peru-de-hoy>. [Consulta: 20 de Setiembre del 2016.]

- Oficina Nacional de Procesos Electorales - ONPE (2011). Resultados de las elecciones generales del Perú 2011-2016 <http://www.americaeconomia.com/politica-sociedad/politica/medios-y-poderen-el-peru-de-hoy>. [Consulta: 20 de Setiembre del 2016.]

- RPPNoticias (2011). Conozca las principales propuestas del presidente Ollanta Humala. RPP, Julio. <http://www.rpp.com.pe/2011-07-28-conozcalas-principales-propuestas-del-presidente-ollanta-humalanoticia 389191.html>. [Consulta: 06 de Diciembre del 2015.]

- Segura Varsi, Alonso (2011). ¿Gastar más o gastar menos? Gestión, Mayo. <http://gestion.pe/impresa/noticia/gastar-mas-gastar-mejor/2011-0523/32755>. [Consulta: 18 de Setiembre del 2015.]

- Unión Europea (2000).Informe conjunto sobre la inclusión social. UE. $<$ http://eur-

lex.europa.eu/LexUriServ/LexUriServ.do?uri=COM:2003:0773:FIN:ES:PDF

$>$ [Consulta: 30 de Setiembre del 2015.] 


\section{ANEXOS}

Se presentan las tablas de frecuencia de las noticias analizadas tanto de El Comercio como de La República en un CD adjunto.

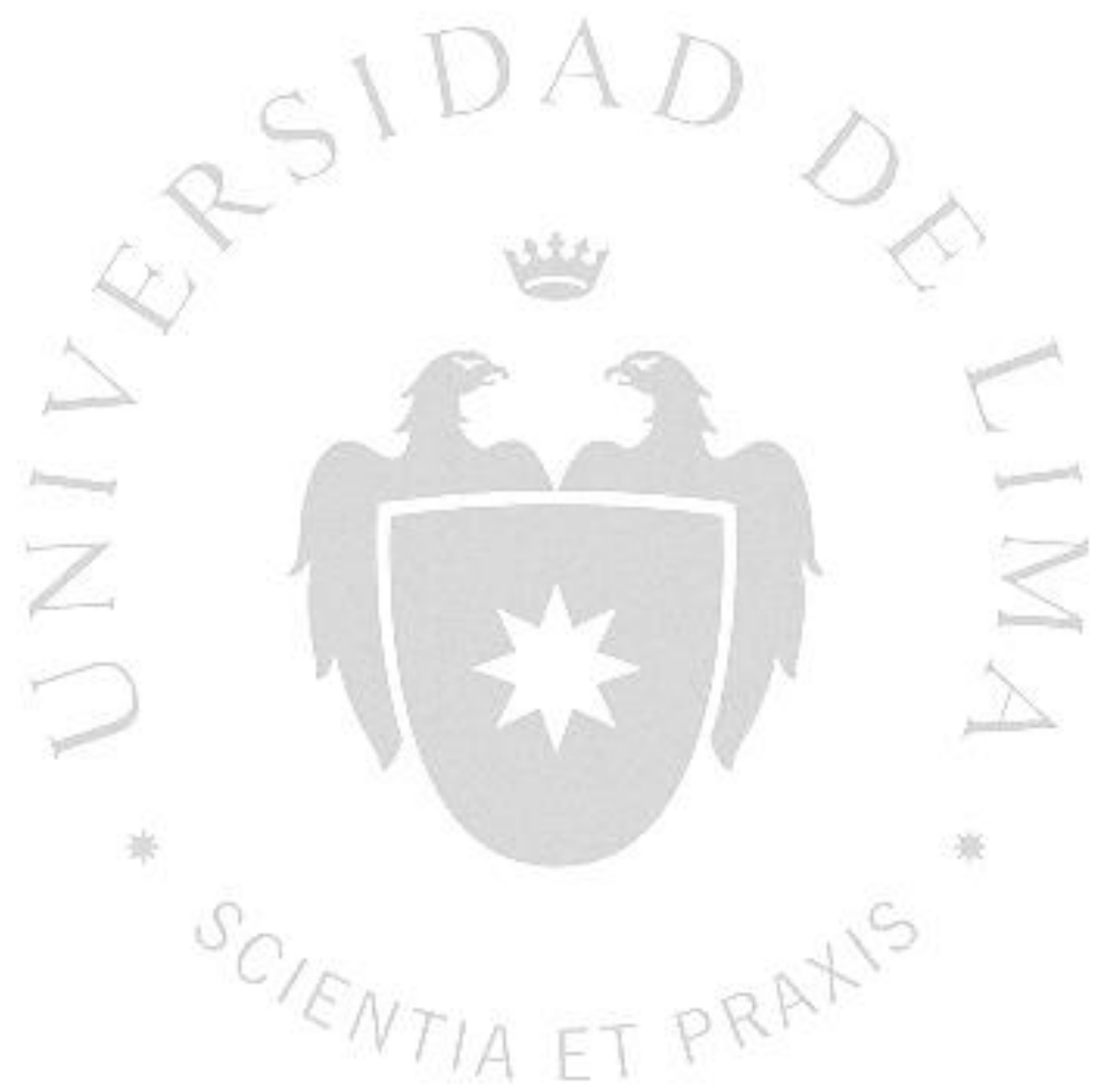

